\title{
The 2016 red tide crisis in southern Chile: Possible influence of the mass oceanic dumping of dead salmons
}

\author{
Armijo Julien ${ }^{1,2,{ }^{*}}$, Oerder Vera ${ }^{3}$, Auger Pierre-Amaël ${ }^{3,4}$, Bravo Angela ${ }^{5}$, Molina Ernesto ${ }^{6}$
}

1 Pontificia Universidad Católica de Chile, Santiago, Chile

2 Centro de Investigación en Recursos Naturales y Sustentabilidad, Universidad Bernardo O'Higgins, Santiago, Chile

3 Instituto Milenio de Oceanografía and Escuela de Ciencias del Mar, Pontificia Universidad Católica de

Valparaíso, Valparaíso, Chile

${ }^{4}$ Laboratoire d'Océanographie Physique et Spatiale, Université de Brest, CNRS, IRD, Ifremer, Brest,

France

5 Universidad de Chile, Santiago, Chile

6 Universidad de Santiago, Santiago, Chile

*Corresponding author : Julien Armijo, email address : julienarmijo@gmail.com

\begin{abstract}
:
In 2016, a massive harmful algal bloom (HAB) of Alexandrium catenella around Chiloé island caused one of the major socio-ecological crisis in Chilean history. This red tide occurred in two distinct pulses, the second, most anomalous, bursting with extreme toxicity on the Pacific coast, weeks after the highly controversial dumping off Chiloé of $4,700 \mathrm{t}$ of rotting salmons, killed by a previous HAB of Pseudochattonella verruculosa. We study the transport of this pollution, analyzing the physical oceanographic conditions during and after the dumping. We find that a cyclonic gyre was present between the dumping site and the coast, visible in satellite altimetry and sea surface temperature data. Using Lagrangian simulations, we confirm that near-surface currents could have brought part of the pollution to the coast, and fueled the bloom. This scenario explains also the anomalous later finding of ammonium near Chiloé. Finally we discuss the mismanagement of risk throughout the events.
\end{abstract}

\section{Highlights}

- Some rotting salmon biomass could have fueled the extraordinary 2016 red tide. A cylconic gyre was present between the pollution location and Chiloé's coast. Part of the salmon pollution off Chiloé could have reached coastal surface waters. Transported salmon biomass can explain the coastal ammonium patch found later.

Keywords : Harmful algal blooms, Aquaculture, Pollution control, Ocean transport, Ecological crisis, Risk management 


\section{INTRODUCTION}

During the austral summer and autumn of 2016, one of the major social and environmental crisis in Chilean history occurred in the southern waters around the island of Chiloé [Mascareño 18] (see Fig. 1). The catastrophic sequence of events involved two major HABs. The first one was a bloom of Pseudochattonella verruculosa (locally called "brown tide"), that killed 40,000 tons of salmon from farms in the northern part of the Chiloé inland sea (CIS), and was related to strong climate anomalies [León-Muñoz 18, Garreaud 18]. The second HAB was a "red tide" of $A$. catenella, a dinoflagellate that produces paralyzing shellfish toxins (PST) that can be deadly to humans by consumption of infected mollusks. The red tide occurred in two pulses, the second of which was the most anomalous, and destructive, since it covered waters on the Pacific coast of Chiloé and further North in Los Rios region, never before affected by a red tide in blooming conditions [Mardones 10]. This second pulse surprised many by its magnitude and extreme toxicity, but its causes are not yet well understood [Buschmann 16, Strub 19].

In southern Chile, the salmon industry has been deployed massively since the 1980 s, with current production reaching about 800,000 tons/yr [SalmonChile 18]. The feed, which is entirely allogenous, represents a huge injection of nutrients in the protected coastal waters, since about $2 / 3$ of the $\mathrm{N}$ and $\mathrm{P}$ is left to the ecosystem as uneaten feed and excreta [Bouwman 13b], that is, for each ton of salmon produced, about $49 \mathrm{~kg} \mathrm{~N}$ and $8 \mathrm{~kg}$ $\mathrm{P}$ [Bouwman 13a]. Comparing to the $12 \mathrm{~g} \mathrm{~N}$, and $3 \mathrm{~g}$ $\mathrm{P}$ released daily by each human in urines and excreta [Folke 94, Rose 15], currently the Chilean salmon industry is equivalent to the untreated human waste of 9 million people, considering $\mathrm{N}$ (or 6 million, considering $\mathrm{P}$ ), being discharged every day in the upper coastal waters of the CIS and Patagonian fjords.

This massive nutrient enrichment in these water bodies where eutrophication is already favored by the partial confinement, has been identified for a long time as a serious threat causing the risk of region-scale eutrophication, and having possibly favored the expansion of red tides from southern Patagonia northward in the last decades, and their intensification [Arzul 01, Iriarte 07, Buschmann 09, Trainer 19]. Several isolated studies in specific locations have documented strong impacts of salmon farms on the benthic life, such as anoxic conditions (routinely reported by the industry), biodiversity collapse [Soto 04], or azoic conditions [Mulsow 06]. Also, [Buschmann 06] reported a striking 50-fold enhancement of dinoflagellates growth in vivo by salmon farm effluents, and a strong pulse of dinoflagellates near a newly installed fish farm. However, a region-scale assessment of eutrophication due to the salmon industry has, to date, never been conducted, neither by measurements, nor by modeling. 

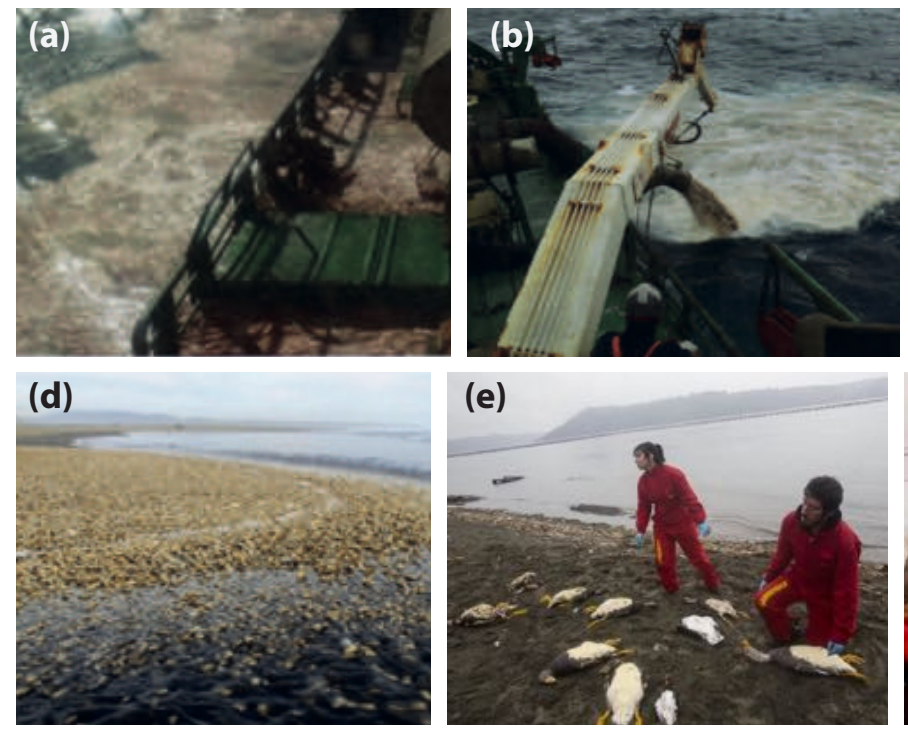

(e)

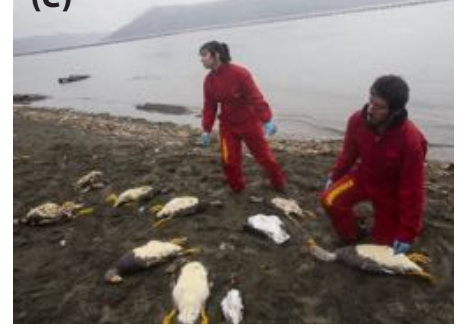

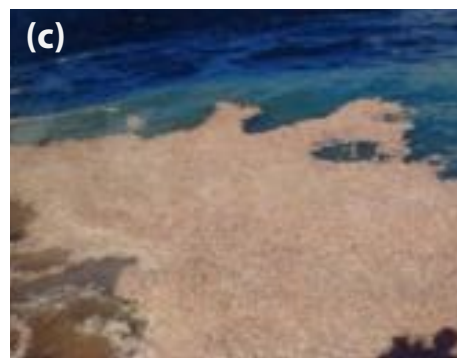

(f)

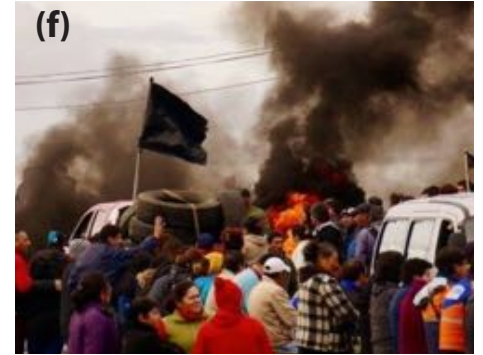

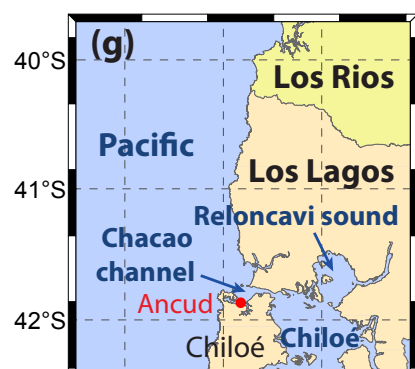

Cucao $\quad$ inland

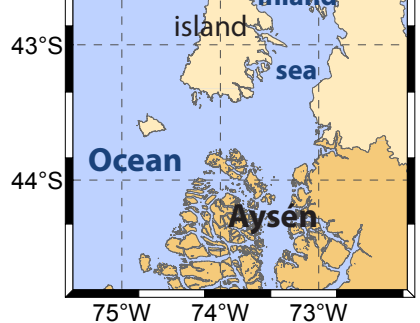

FIG. 1: The salmon dumping and the 2016 red tide crisis. First row : the dumpings. a) Dumping by underflowing b) Dumping with pump. c) Floating pollution. Pictures from [Directemar 16]. Second row : The crisis. d) Dead clams on Cucao beach on April 26. e) Greenpeace team collecting dead birds near Ancud. f) Protests and social upheaval. g) Map of the area.

Besides the permanent risks of eutrophication, in 2016, a singular event which triggered much controversy, but whose impact was not satisfactorily assessed, was the massive oceanic dumping off Chiloé's coast of 4,700 tons of dead salmons, possibly accompanied by unknown chemicals. The dumping, and the actions of the Chilean environmental regulatory administrations, have been very criticized by local fishermen and citizens [Mascareño 18], and were recently condemned by an extraordinary statement of the supreme court [CorteSuprema 18]. During the crisis, intense controversy led the government to call a scientific commission to investigate the causes of the red tide. Its final report [Buschmann 16] dismissed the possibility that the dumping could have fueled the red tide.

In this work, we carefully analyze oceanographic patterns using satellite data, and, using a high resolution model, we simulate the transport of pollution from the dumping location and its vicinity. Our analysis reveals the presence of a robust cyclonic gyre positioned between the dumping location and the coast, and our Lagrangian simulations show qualitatively that near-surface currents could well have transported part of the pollution to the coast, and thus, have fueled or possibly triggered, the explosive and highly toxic second pulse of the 2016 red tide. We also discuss the climate anomalies, studied as well in [Garreaud 18, Strub 19], in particular, the sustained northward winds in the summer and a strong upwelling pulse in March, that could also have favored the bloom. Finally, we discuss the large deficiencies in the risk management throughout the crisis.

\section{THE 2016 CRISIS : CHRONOLOGY}

Let us first summarize the events. Figure 2 shows the evolution of the presence of A. catenella in Los Lagos (X), Aysén (XI) and Los Rios (XIV) regions, with data from the Chilean fisheries institute (IFOP, https://www.ifop.cl/marearoja/), gathered in key periods. Most observers, including [Buschmann 16], have described the 2016 bloom of $A$. catenella in two pulses, or phases.

\subsection{First pulse of the red tide}

The first pulse (Fig. 2.a-b) occurred from January to March, mostly in Aysén region and the southern third of the CIS, with toxicity in mollusks detected on the whole southern coast of Chiloé [Buschmann 16]. During March (Fig. 2.b), A. catenella expanded a bit further in the CIS, to about half of it, leaving the northern CIS uncontaminated. Then, in late March and early April, it showed signs of decline and retrocession especially in the CIS [Buschmann 16], as seen on Fig. 2.c.

\subsection{Brown tide and the dumping of dead salmon}

In parallel, during February 2016, a massive bloom of a different species, Pseudochattonella verruculosa ("brown tide") killed a record reported amount of 40,000 tons of salmon, mostly in the northern CIS and the Reloncavi sound [Buschmann 16]. The total mortality of 25 mil- 

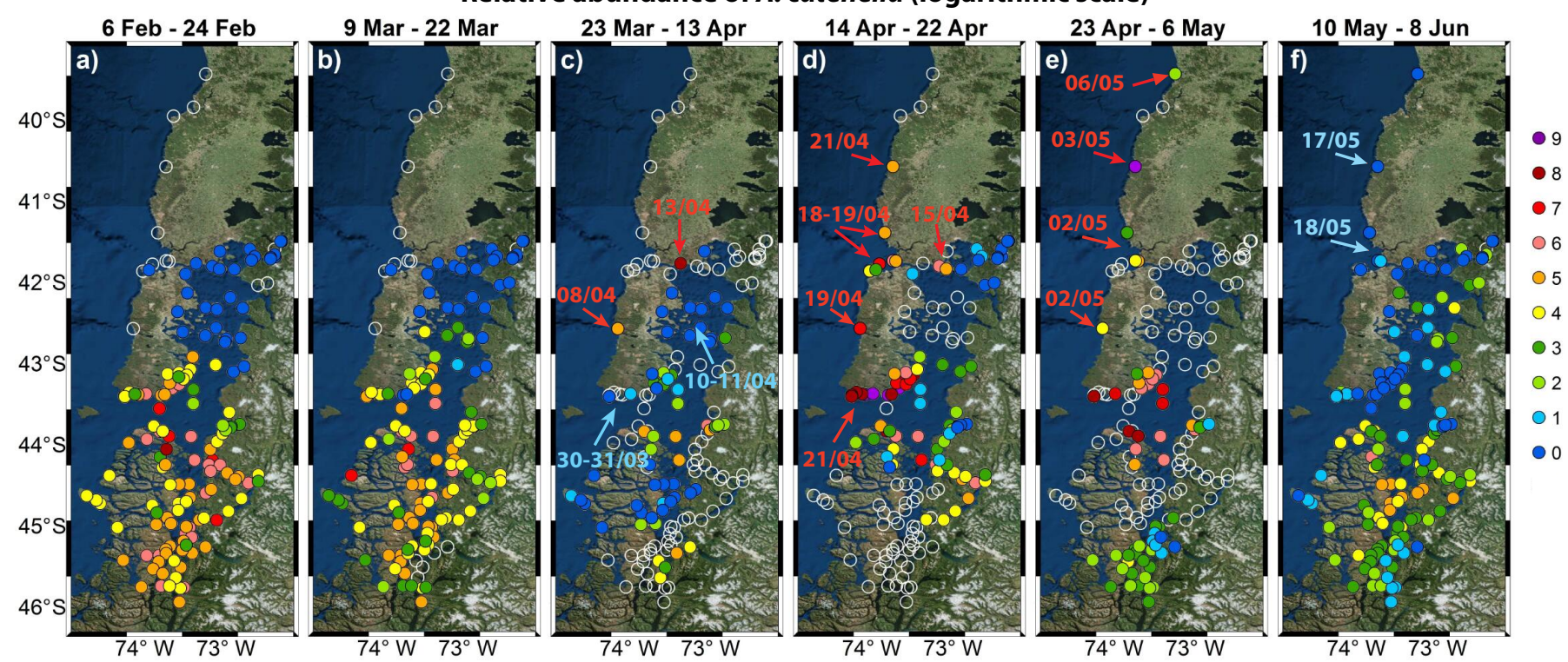

FIG. 2: First and second pulses of the 2016 red tide. Abundance of A. catenella, data from IFOP, grouped in key periods. The logarithmic levels are, in Cells/mL : 0: [0], 1: [<2], 2: [<11], 3: [<43], 4: [<171], 5: [<683], 6: [<2,731], 7: [<10,923], 8: $[<43,691], 9:[<174,763]$, and empty circles refer to no data acquired. a)-b) : First pulse of red tide in Aysén and the southern CIS. c) : Intermediate recession period. c)-e) Second pulse of red tide centered on the Pacific coast of Chiloé. Red arrows show the second pulse of red tide (level $\geq 2$ ), light blue arrows show its absence (level 0 or 1 ), before or after it.

lion fish, representing $12 \%$ of the living salmons at the time, in 45 farming sites, was collected by 158 boats, each carrying from 40 to 1,800 tons. Several strong climate anomalies related to the record 2015-2016 El Niño, have been proposed to explain this massive bloom : mainly, a strong drought with record low pluviometry, reduced fresh water discharges and increased water temperatures and stratification [León-Muñoz 18, Garreaud 18].

The mortality was so massive, that it could not be processed in regular ways, by dumping in landfills or reduction to fishmeal [Buschmann 16]. On March 3, the industry syndicate SalmonChile asked permission to dump rotting salmons into the ocean and, on March 4, an extraordinary permit was granted to dump 9,000 tons of dead fish, at 75 nautical miles (NM), i.e. $139 \mathrm{~km}$ off Punta Faro Corona, on Chiloé's island N-W edge, in a zone of radius $5 \mathrm{NM}(=9.3 \mathrm{~km})$ [Sernapesca 16b]. This authorization, was later on, highly criticized (see §5.3).

From March 11 to 26, the Chilean navy supervised the dumpings, realized by 7 boats, in the sequence depicted in Fig 3. Note that, the navy report [Directemar 16] considered a location $41.771^{\circ} \mathrm{S}, 75.725^{\circ} \mathrm{W}$ while the position $75 \mathrm{NM}$ West of Faro Corona is $41.785^{\circ} \mathrm{S}, 75.57^{\circ} \mathrm{W}$. In all following figures, we show the former as a red circle, and the latter as an orange circle.

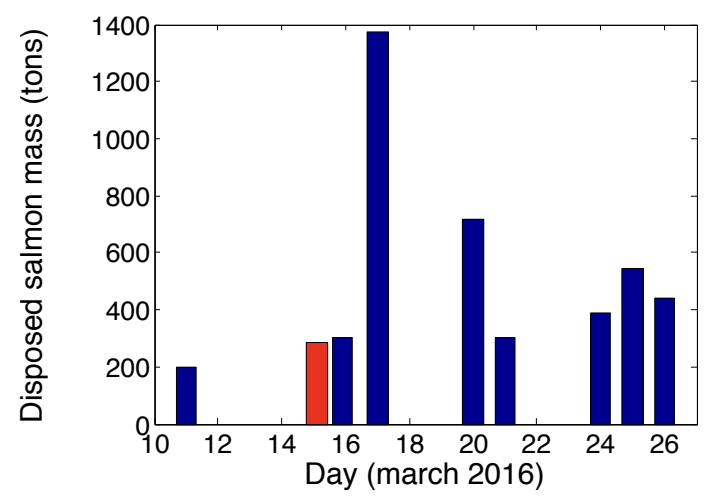

FIG. 3: Sequence of dumpings (total 4,655 tons) of dead salmons, by 11 boat trips, as reported by [Sernapesca 16b]. The red bar is a dumping outside the authorized zone, closer to the coast.

\subsection{Second pulse of the red tide}

The second pulse of red tide (Fig. 2.c-e), bursted in early and mid-April, on the Pacific coast of Chiloé, after the intermediate low in late March and early April (Fig. 2.c). It covered an area where no bloom had previously been recorded, from about $43.5^{\circ} \mathrm{S}$ up to $39.4^{\circ} \mathrm{S}$ in Los Rios region (Fig. 2.e). This second pulse showed very high cell concentrations (Fig. 2.c-e) and very high measured toxicities in mollusks. [Buschmann 16], suggested 
that the second pulse originated from the northern Aysén region, extending along the pacific coast of Chiloé. However, one can also think that it could have originated offshore and have then hit the coast (see $§ 5$ ).

The first detection of PST above the norm $(80 \mu \mathrm{g}$ saxitoxin equivalent (STXeq)/100g mollusk flesh) occurred in Cucao on April 5, with $280 \mu \mathrm{g}$ STXeq/100g, and after April 8, it started increasing exponentially [Buschmann 16]. The first detection by IFOP of high abundances of $A$. catenella on the Pacific coast was on April 8 in Cucao, at level 5 (Fig. 2.c). Note that IFOP measurements on the Pacific coast were extraordinary, triggered by the 2016 crisis. On Fig. 2-d, one sees the second pulse at its peak, taking Chiloé's island as a claw, covering all of its Pacific coast, reaching extreme concentrations on the southern part, and present on both sides of the Chaco channel.

The northern CIS is separated from the southern CIS by the archipelago of Islas Desertores (see Fig. 1.g), and has never shown proliferation of $A$. catenella, probably due to the important fresh water discharge from the Puelo river [Mardones 19]. Considering that the red tide was completely absent from the northern CIS in all February and March, and until April 10-11, but appeared suddenly in it on April 13, at level 8, near the Chacao Channel (Fig. 2.c), then propagating inside the CIS, loosing intensity (Fig. 2.f), the well favored hypothesis is that $A$. catenella cells penetrated in the uncontaminated northern CIS from Pacific waters, via the Chacao channel, in early and mid-April [Mardones 19]. Such mechanism is also the favoured hypothesis explaining the detection in 2009 of some sparse cells of A. catenella (not blooming) on the Pacific coast of Chiloé in the autumn, long after the bloom, which had taken place in Aysén and the southern CIS in March and April [Mardones 10]). Transport through the Chaco channel is indeed favored by the strong tidal currents which have semi-diurnal cycles that can exceed $4 \mathrm{~m} / \mathrm{s}$ for spring tides, and about half with neap tides [Artal 19]. In 2016, maximal new moon tidal currents were on April 6. Considering, for example, a sinusoidal semi-diurnal cycle of amplitude 3 $\mathrm{m} / \mathrm{s}$ (see Fig. 2 in [Artal 19]), the average current over each 6 hours semi-period is $1.9 \mathrm{~m} / \mathrm{s}$, yielding a transport over $41 \mathrm{~km}$, well sufficient to bring offshore cells across the only $20 \mathrm{~km}$ long Chacao channel, inside the CIS.

A maximum of 250,000 cells $/ \mathrm{mL}$ was recorded in the Chacao channel the last week of April [Hernández 16]. After May 2, the peak was passed, and no concentration above level 1 was detected on the Pacific coast or the Chacao channel, however low levels up to 4 were still measured in the Northern CIS during May (Fig. 2.f).

\subsection{Strange deaths, social and economic crisis}

The "2016 red tide crisis" was not only an extraordinary oceanographic event, it also turned into a major social crisis, with strong economic and political consequences, including an intense social conflict and mediatic debate.

The first major issue was the massive mortalities observed. From mid-April 2016 through May, several sources reported anomalous mortalities on Chiloé's Pacific coasts, especially of bivalves, birds (see Fig. 1.e) and other shellfish and macroalgae, found dead on the beaches [Buschmann 16, Greenpeace 16]. The local Maritime Governor found very suspicious the washing ashore of dead giant barnacles ("picorocos"), and asked which chemicals were used in the dumpings [INDH 16]. Unfortunately, no detailed reports were made for these events, despite massive press coverage. The most commented event was the stranding of 830 tons of dead clams (Mesodesma donacium) from April 26, over $5 \mathrm{~km}$ of beaches in Cucao [Sernapesca 16c], as seen in Fig. 1.d. This event, although spectacular, could be explained by the paralyzing toxin of the red tide, however, no such events were noted previously or later in any red tide events in Chile [Mascareño 18].

As for economic impact, the red tide led to the closure of up to $500 \mathrm{~km}$ of shellfish harvesting [Hernández 16]. After the dismissal of 4,500 salmon workers due to the brown tide, the red tide caused 6,000 divers and fishermen to lose their livelihoods [Mascareño 18]. From the beginning of the crisis, local populations in Chiloé, accused the salmon industry and the government of having "poisoned the ocean". Dead salmon is known to release toxic sulphuric acid [SMA 16a], moreover, the possible chemicals accompanying the rotting biomass were not even characterized [CorteSuprema 18], and illegal dumpings outside the official zone were suspected (see $\S 5.3)$. Protests started being carried in Chiloé, and access to the island was shut down for 17 days. Due to the magnitude of the crisis, on May 10, the economy minister called for a scientific investigation via the $\mathrm{Na}$ tional Science Academy, whose final report was delivered in November [Buschmann 16].

\section{OCEANOGRAPHIC CONDITIONS DURING AND AFTER THE DUMPING}

One key question concerning the 2016 red tide crisis, is to understand how the pollution of dead salmons may have been transported after the dumping. To address it, we first analyze in this section the oceanic conditions during and after the dumping. This analysis is necessary to interpret the results of the modeling that we develop in Section 4. In particular, we describe here the robust cyclonic gyre that was present during all April between the 
dumping location and the coast, and which is consistent with surface temperature observations. The analysis of winds contributes to the understanding of surface transport patterns, and chlorophyll data complete the picture.

\subsection{Data sources}

We obtain altimeter daily data and monthly means from the European Copernicus Marine Environmental Monitoring Service (http://marine.copernicus.eu/). We use the L4 product 008-047, which is reprocessed from all altimeter missions, and has $1 / 4^{\circ}$ resolution, i.e., about $21 \mathrm{~km}$ latitudinally, and $28 \mathrm{~km}$ longitudinally.

To analyze the wind forcing, we use IFREMER CERSAT Global Blended Mean Wind Fields L4 data, available from http://marine.copernicus.eu/ (product 012004), which have 6 -hour and $1 / 4^{\circ}$ resolution (see, e.g., [Bentamy 12]), from which we compute daily averages. The data are estimated from scatterometers ASCAT and OSCAT retrievals and from the European Centre for Mid-range Weather Forecasts (ECMWF) operational wind analysis.

To study sea surface temperature (SST) patterns, we use the Group for High Resolution Sea Surface Temperature (GHRSST) Level 4 Multi-scale Ultra-high Resolution (MUR) datasets produced at the JPL Physical Oceanography DAAC, available at https://podaac.jpl.nasa.gov. To quantify the upwelling of cold, deeper waters, we switch to a longer term, lower resolution $\left(1 / 4^{\circ}\right)$ analysis, using data from the GHRSST Multi-Product Ensemble (GMPE) system, available from http://marine.copernicus.eu/ (product 010-005).

To study chlorophyll-a patterns, we use daily GlobColour CHL1 data from the MODIS sensor, processed with the AV algorithm, available from http://hermes.acri.fr/, at $4 \mathrm{~km}$ resolution.

\subsection{Surface geostrophic currents}

Let us first note, that the regional oceanography of the Pacific off Chiloé has been little studied (see, e.g., [Aguirre 14] and references therein). Recently, [Strub 19] studied in detail the south Pacific between $38^{\circ}$ and $46^{\circ}$ which is the transition zone where the eastward Pacific current splits between the northward Humboldt current and the southward Cape Horn current. Considering averages in the 1993-2016 period, they showed that the boundary between them migrates seasonally following the south Pacific anticyclone (see Fig 5 of [Strub 19]), from $\sim 51^{\circ} \mathrm{S}$ during austral summer, to $\sim 37^{\circ} \mathrm{S}$ in winter. Autumn is thus the transition period, during which currents off Chiloé switch from northward to southward.

In figure 4, we show monthly averages of the sea surface height (SSH) relative to the geoid, or absolute dy- namic topography, which allows to visualize the general surface geostrophic circulation of interest for this work. The surface geostrophic velocities are computed from the satellite-measured SSH maps using the geostrophic balance : $f v_{g}=\frac{1}{\rho} \frac{\partial P}{\partial x} ; f u_{g}=-\frac{1}{\rho} \frac{\partial P}{\partial y}$, where $P$ is the pressure in a near surface layer, $\rho$ the water density, $\left(u_{g}, v_{g}\right)$ the horizontal components of the geostrophic velocity, and $f=2 \Omega \sin (\phi)$ is the Coriolis parameter, with $\Omega=7.3 \times 10^{-5} \mathrm{rad} / \mathrm{s}$ the Earth rotation frequency, and $\phi$ the latitude. These velocities correspond to the near surface current assuming vertical hydrostatic balance, and neglecting vertical variations of the density, and wind effects. The true surface currents can be approximated as the sum of the surface geostrophic current, which describes well the mesoscale current structures, to depths of hundreds of meters (see e.g., [Pegliasco 15]), and the wind-driven Ekman currents (at the surface, tilted $45^{\circ}$ from the wind direction), which are felt in the first tens of meters. Note that at the surface the Ekman current are often stronger than the geostrophic currents

During March, the geostrophic current is essentially northward, forming a jet at a distance from the coast which corresponds to the edge of the upwelling tongue (see $\S 3.3$ ). Closer to the coast, one sees the beginning of a cyclonic gyre, which becomes prominent in April, clearly visible in the altimetry as a negative anomaly about $10 \mathrm{~cm}$ deep. In May, the gyre has vanished and currents are weaker.

Figure 5 shows 6-day averages of SSH data and derived geostrophic currents, to resolve the period of possible transport of pollution to the coast. During most of March, the pattern is that of a summer type, northward wind stressed current. However from about March 20 on, the cyclonic gyre, featuring southward coastal currents starts appearing, becomes very marked during the first half of April, then starts elongating latitudinally, until splitting in two weaker gyres in early May. This gyre, crucial for this study, stands between the dumping zone and the coast, and thus sets sustained conditions for current trajectories from the dumping zone, towards the coast of Chiloé.

\subsection{Winds}

Figure 6 shows daily averaged wind data, in the relevant period, while Fig. 7 presents the daily wind vector, averaged on the rectangle zone shown in Fig. 7.b, as well as its meridional and zonal components.

During the summer 2016, winds in the relevant area have been consistently northward, especially in March, as seen in Fig. 7.a. (see also [Garreaud 18, Strub 19]). The wind direction, however, started changing on March 26, the last day of dumping, after which, during five days from March 27 to 31, it blew towards South and East, favoring transport towards the coast. During April, there 

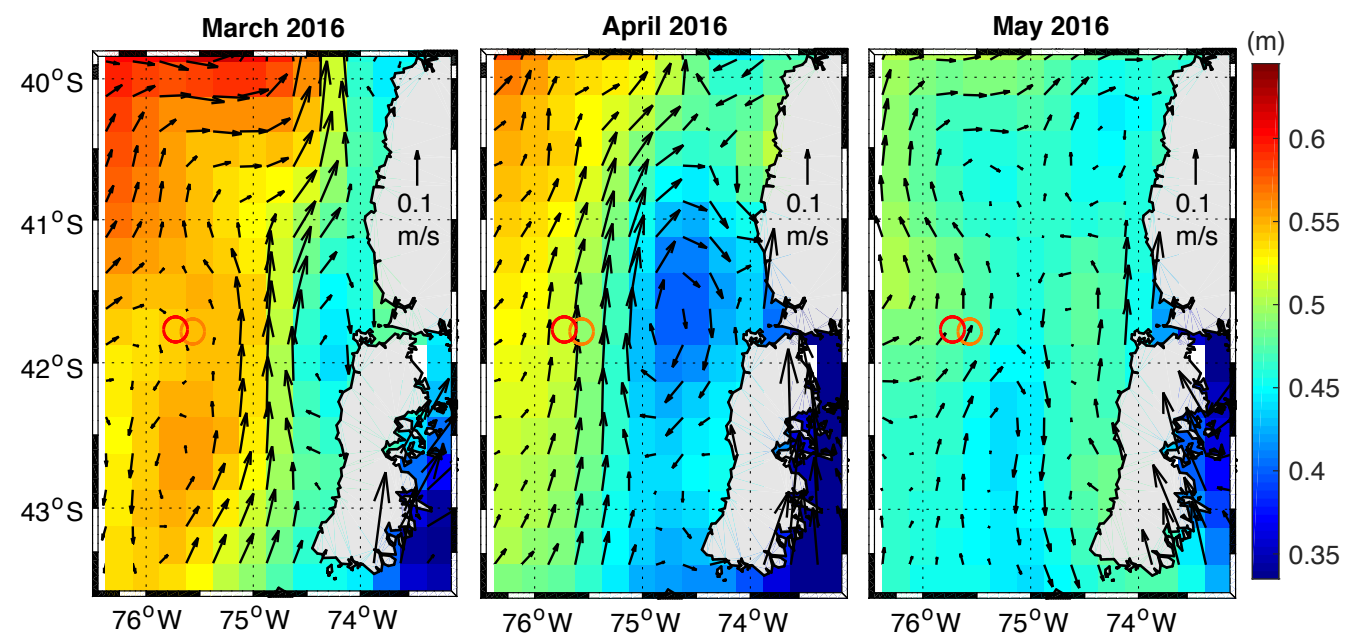

FIG. 4: Monthly averaged satellite measured SSH above geoid and derived geostrophic currents. The red circle shows the authorized dumping zone according to [Directemar 16], the orange circle, the area 75 NM West of Faro Corona (see § 2.2).
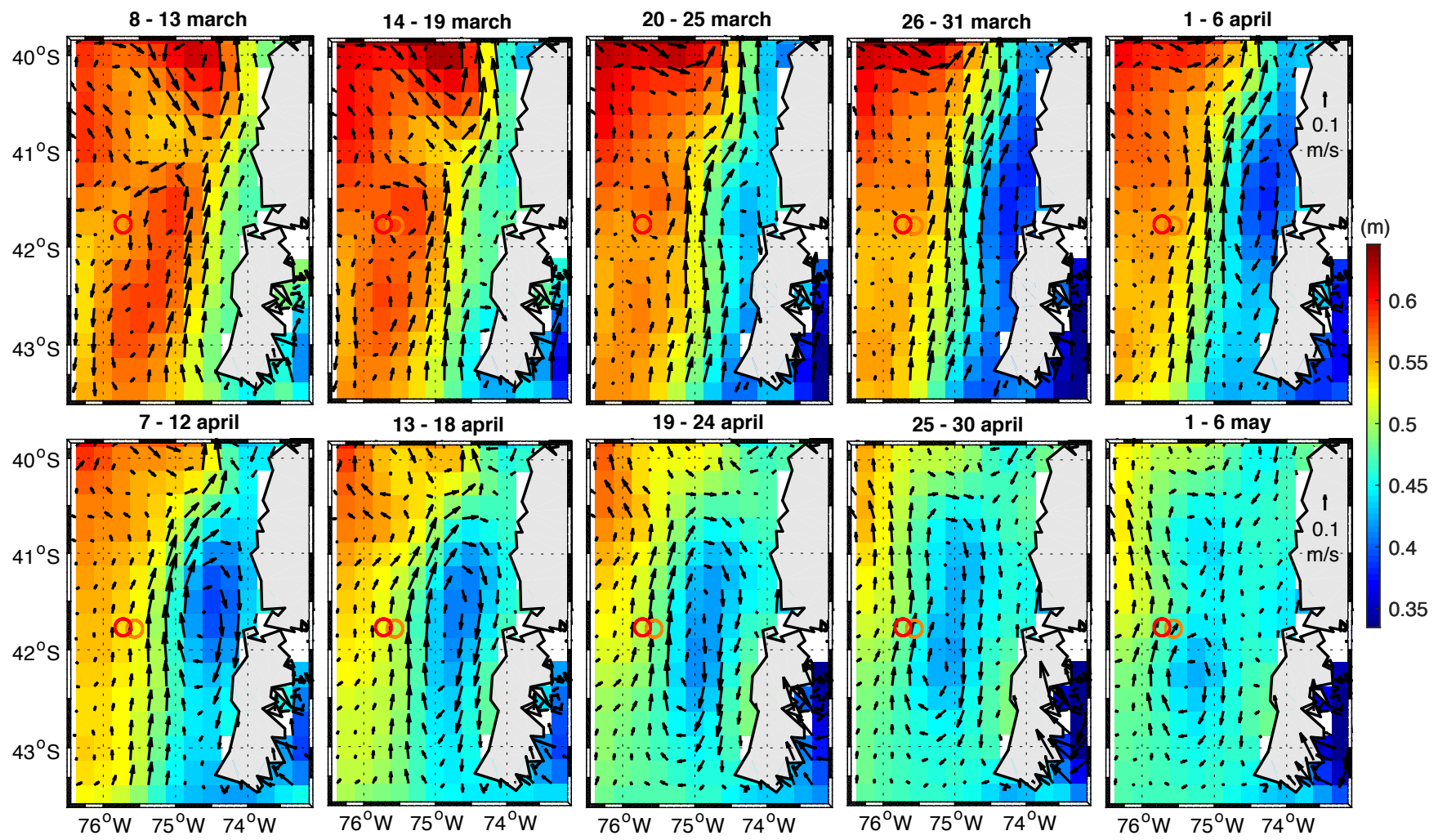

FIG. 5: 6-day averages of satellite measured SSH above geoid and derived geostrophic currents. The data resolution is $1 / 4^{\circ}$.

was an alternation of northward and several episodes of southward wind (marked with stars on Fig. 7.b).

Contrary to [Buschmann 16], where the wind was analyzed only with weekly averages, concluding that winds were essentially northward during the period of interest, our day-to-day analysis shows critically that, between the last days of dumpings and the climax of the second pulse of red tide around mid-April, they presented several multiday sequences keen to drive coastward surface currents. 

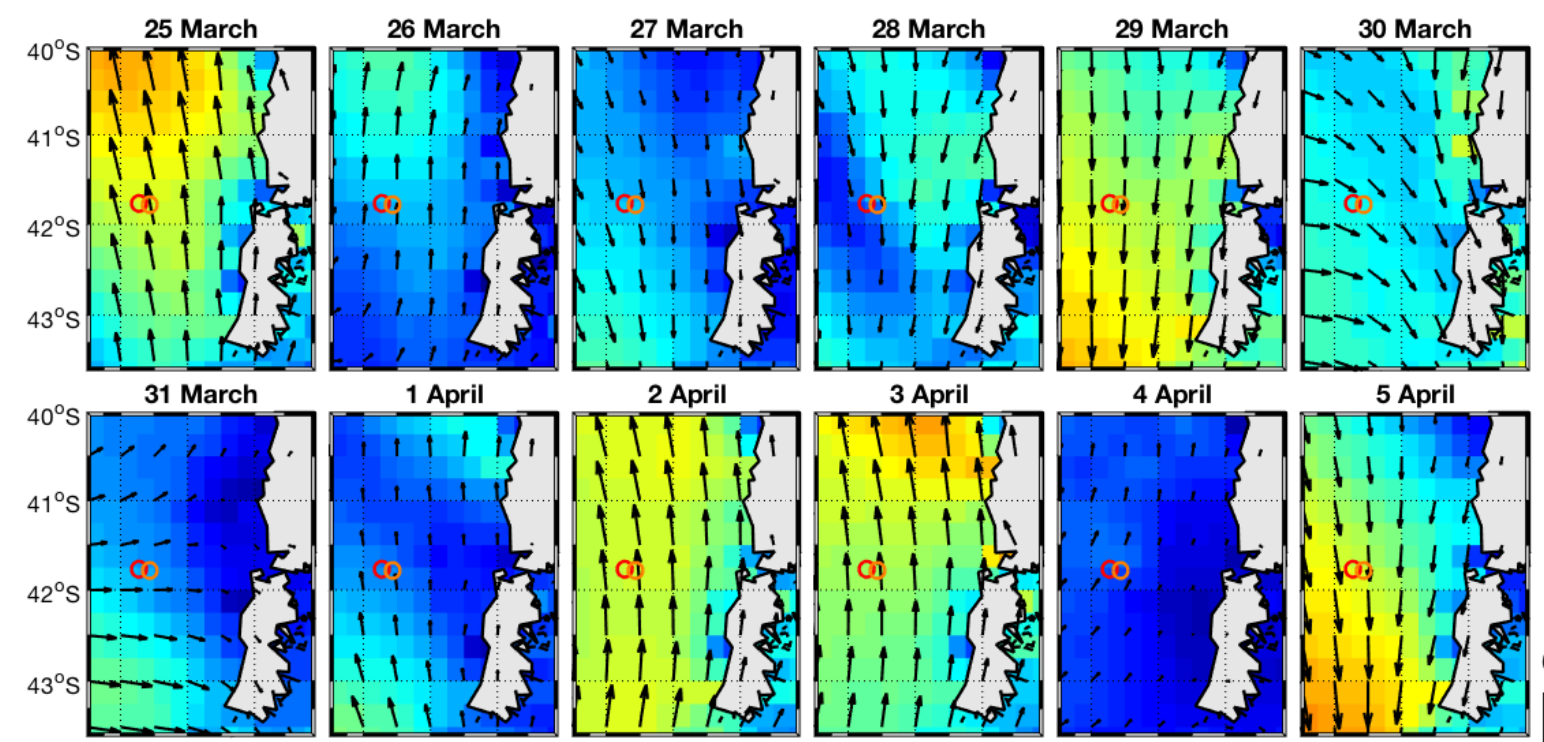

4 April

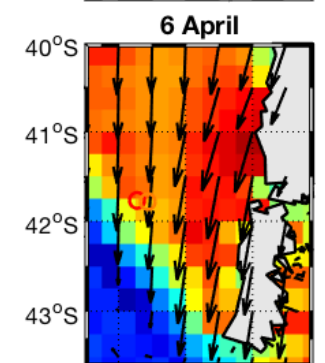

7 April

8 April

9 April

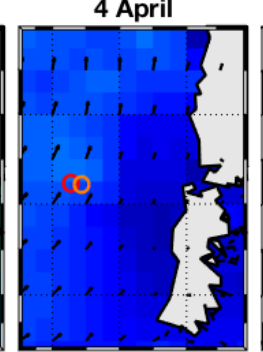

5 April
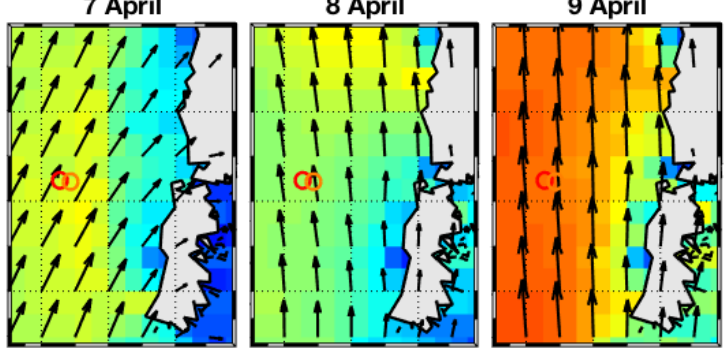

10 April
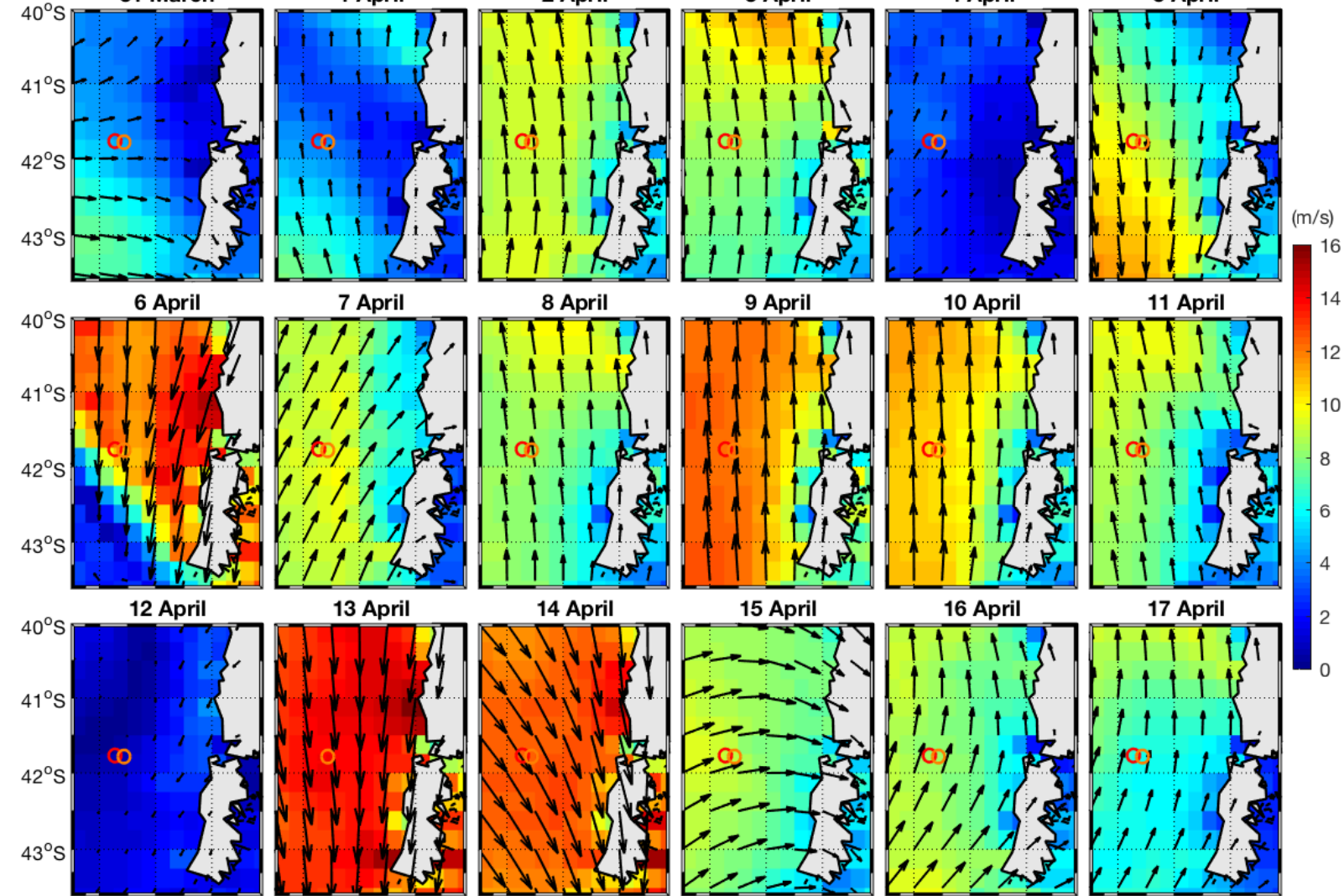

13 April
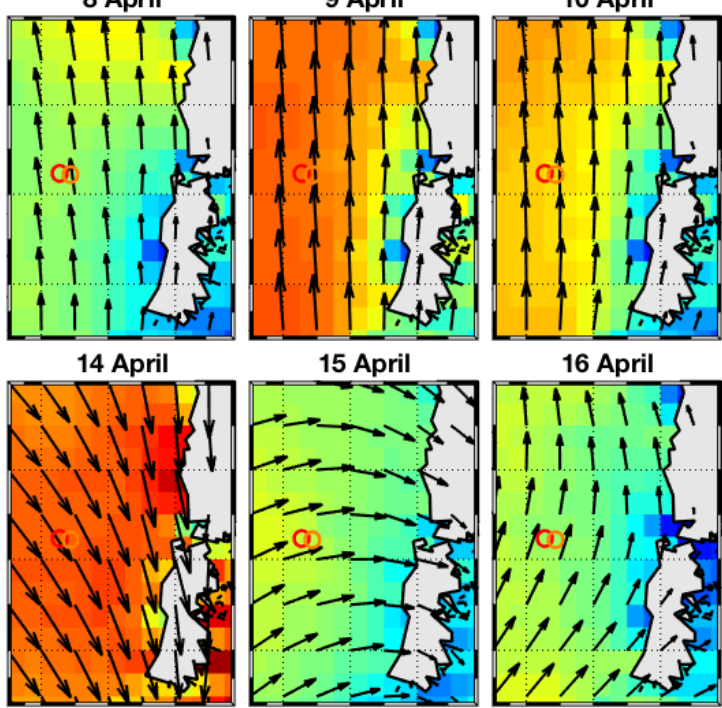

11 April

16 April
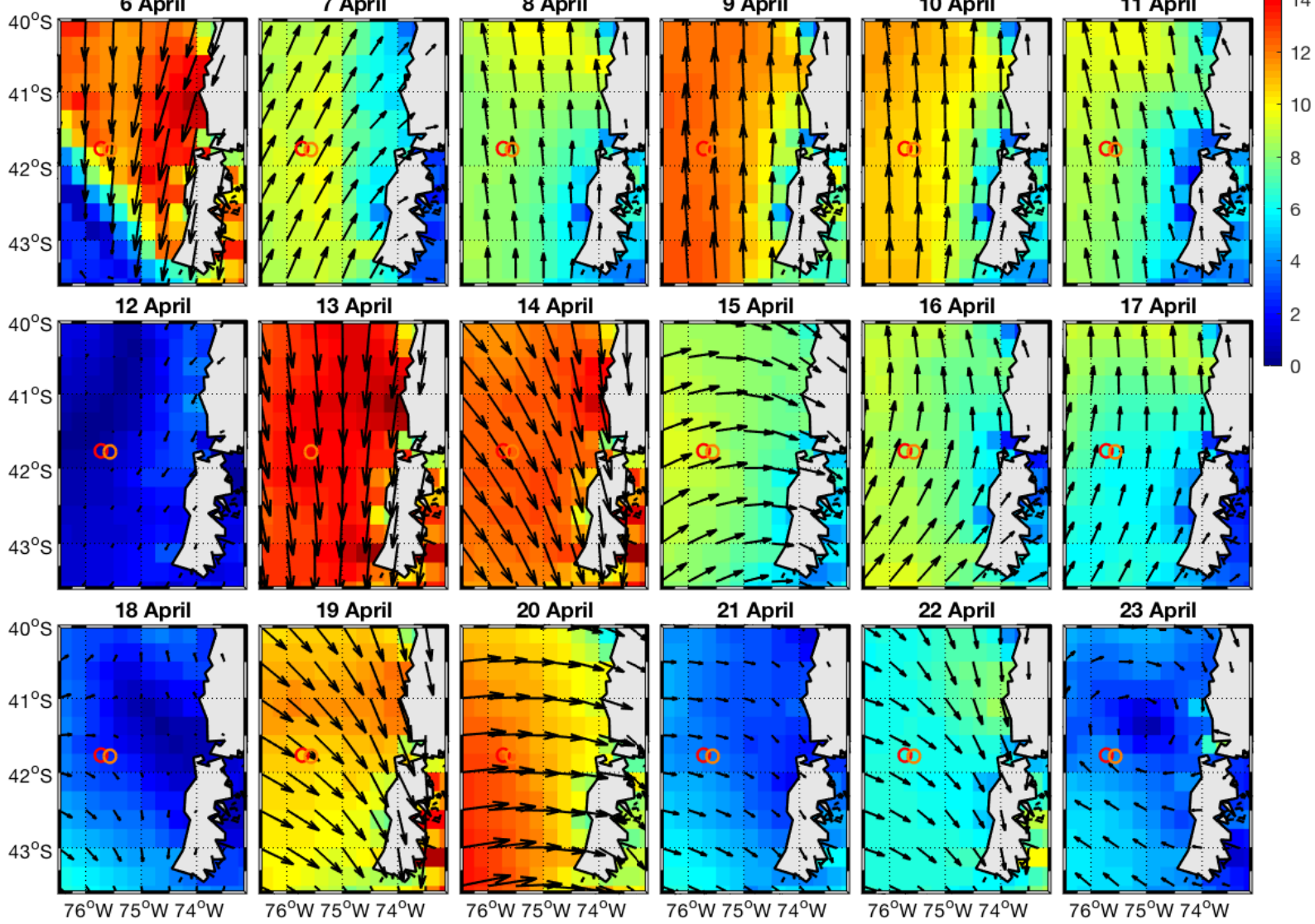

FIG. 6: Daily winds, in the period of interest. Arrow sizes are proportional to wind speeds. The data resolution is $1 / 4^{\circ}$.

\subsection{Surface temperature}

Figure 8 shows SST maps, together with geostrophic currents. In early March, one sees a well-marked coastal upwelling tongue, with lower coastal temperatures than offshore. This pattern then vanishes from late March to
May due to downwelling events, and advection of offshore waters towards the coast, in good agreement with the geostrophic currents. In particular, a tongue of warmer offshore water flowing coastward, on the north and east side of the gyre, is well visible for April 1-6 and later during April (see red circles on Fig. 8). 


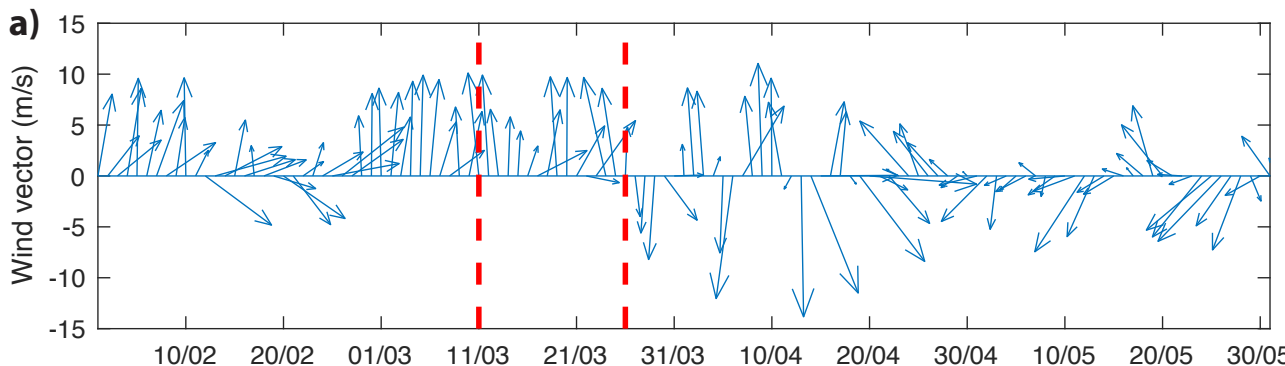

b)
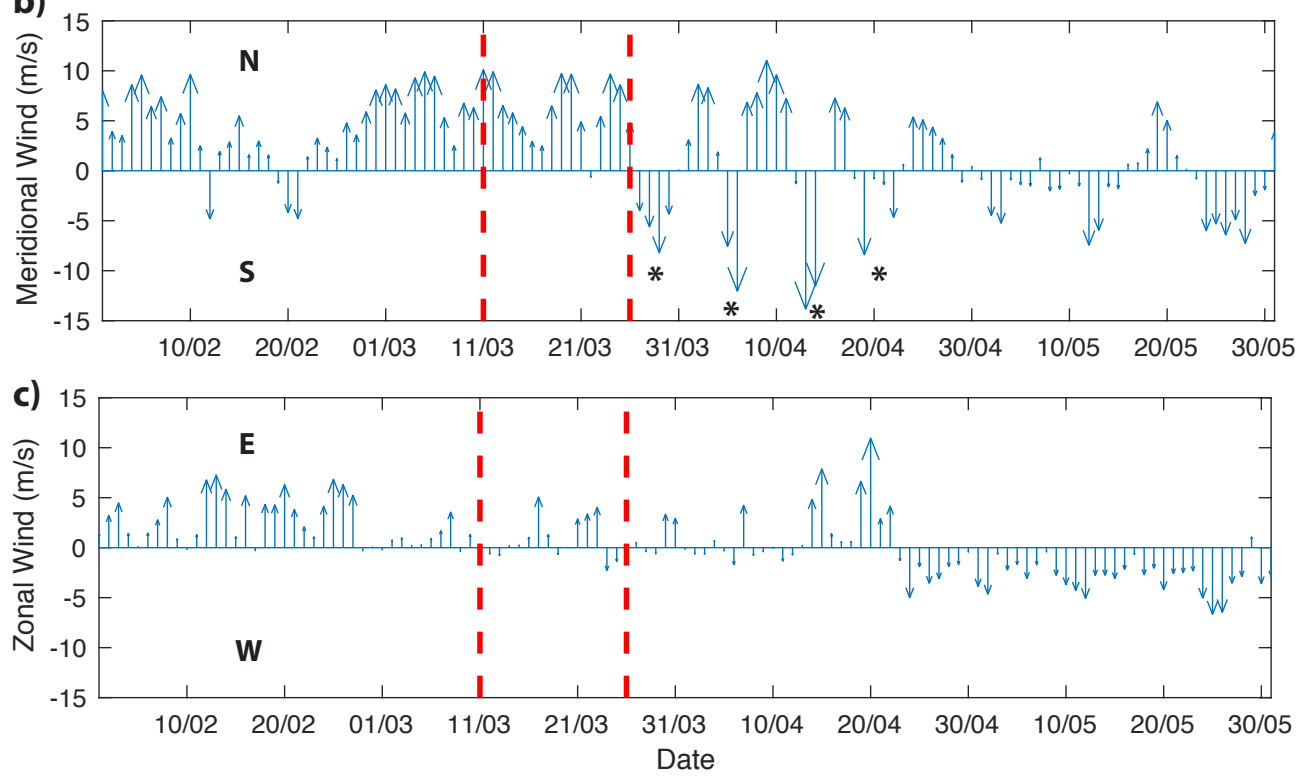

d)

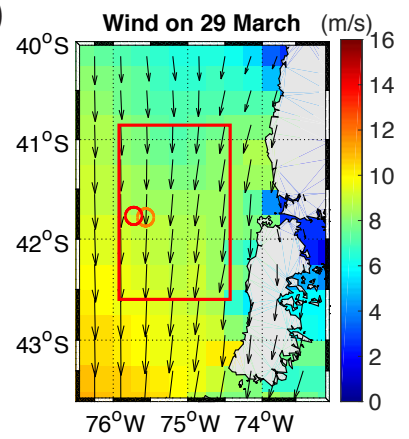

FIG. 7: a) Wind vector from February to May 2016, averaged in the box area shown in d) as red rectangle. Dashed vertical lines indicate the period of salmon dumpings. b) Meridinal component. c) Zonal component. d) Wind map for March 29.

Figure 9 shows the evolution of $T_{1}, T_{2}$, and $\Delta T=$ $T_{2}-T_{1}$, where $T_{1}$ and $T_{2}$ are the coastal and offshore SST, averaged over the two zones shown on Fig. 9.c, respectively defined by a distance to coast $4 \mathrm{~km}<\mathrm{d}<24$ $\mathrm{km}$ and $120 \mathrm{~km}<\mathrm{d}<160 \mathrm{~km}$, and a latitude between $40.5^{\circ} \mathrm{S}$ and $43.5^{\circ} \mathrm{S}$. In all plots, the dashed and continuous lines represent 8-year averages computed over 20102017. In Fig. 9.b, we see $\Delta T \simeq 3.5^{\circ} \mathrm{C}$ towards March 12,2016 , a value substantially above the climatological average of $2.1^{\circ} \mathrm{C}$. This strong upwelling pulse is well explained by the persistent northwards winds in February and March, described above. During March and April, $T_{1}$ near the coast is lower than the average, which eliminates the hypothesis of warm coastal waters as a favoring factor for the red tide. In Fig. 9.d and e, we see that March 2016 has the record $\Delta T$ in the 8-year series. However this anomaly is not extraordinary : values of $\Delta T$ above $2.5^{\circ} \mathrm{C}$ have been recorded several years. [Strub 19] estimated that upwelling favorable conditions (wind stress and currents) during March 2014 and January-February 2015 were "as strong or stronger than in March 2016" (see there, Fig 16b, and text page 27-28).
From mid-March to late April, $\Delta T$ decays rapidly, falling below the average in late April. This relaxation is consistent with the decay of northward wind (see Fig. 7), the change in the geostrophic circulation, including the gyre, and the several episodes in April of southward wind pushing surface water coastward. On Fig. 9.a, we see in late March a rise in $T_{1}$, probably indicating a first important downwelling event. In [Buschmann 16], Fig. 15 also shows prevailing coastward surface currents around $42^{\circ} \mathrm{S}$ during April 2016. Importantly, the upwelling relaxation, and associated coastward flows in the surface layer of warmer, lighter water, have long been recognized as a prominent physical feature for the development of HABs, often in relation with increased water column stratification [Pitcher 10].

\subsection{Chlorophyll}

Figure 10 shows chlorophyl maps gathered in 6-day composites. From March 2 to 26, important photosynthetic biomass was present offshore Chiloé, probably 


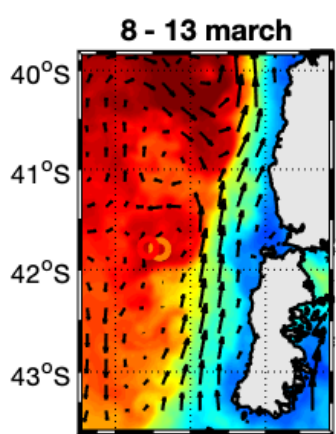

$13-18$ april

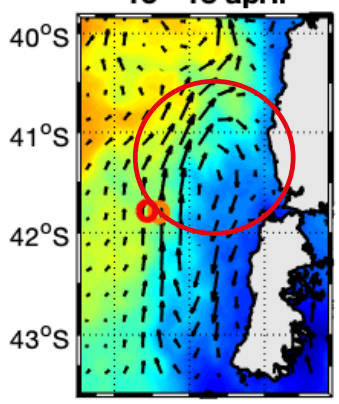

$76^{\circ} \mathrm{W} 75^{\circ} \mathrm{W} 74^{\circ} \mathrm{W}$
14 - 19 march

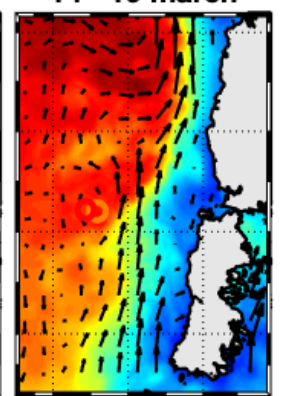

19 - 24 april

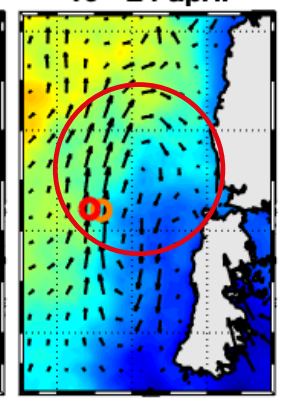

$76^{\circ} \mathrm{W} 75^{\circ} \mathrm{W} 74^{\circ} \mathrm{W}$
20 - 25 march

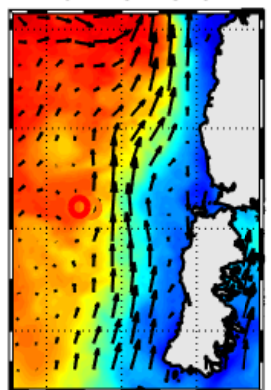

25 - 30 april

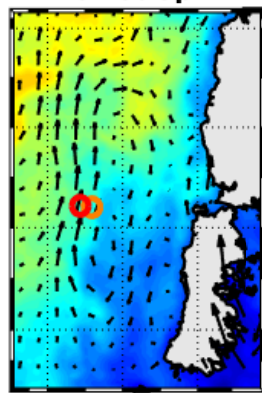

$76^{\circ} \mathrm{W} 75^{\circ} \mathrm{W} 74^{\circ} \mathrm{W}$

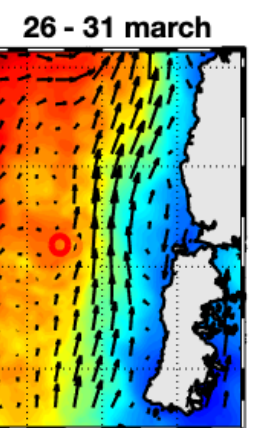

1 - 6 may

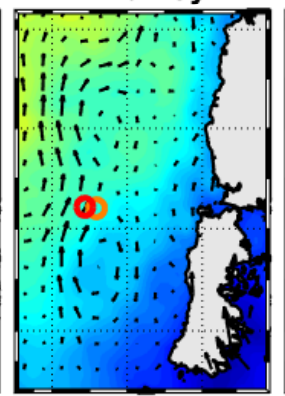

$76^{\circ} \mathrm{W} 75^{\circ} \mathrm{W} 74^{\circ} \mathrm{W}$
$1-6$ april

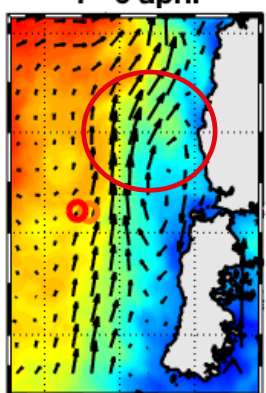

7 - 12 may

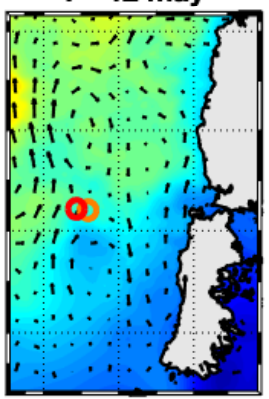

$76^{\circ} \mathrm{W} 75^{\circ} \mathrm{W} 74^{\circ} \mathrm{W}$
7 - 12 april

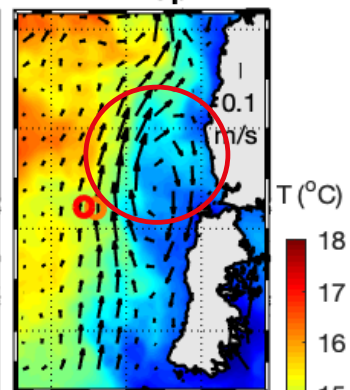

13 - 18 may

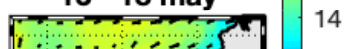

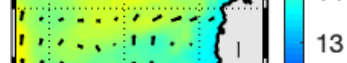

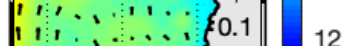

$1 \mathrm{~m} \mathrm{~m}^{\mathrm{m} / \mathrm{s}}$

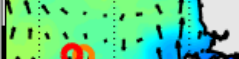

1'.

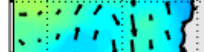

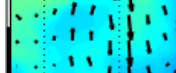

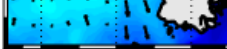

$76^{\circ} \mathrm{W} 75^{\circ} \mathrm{W} 74^{\circ} \mathrm{W}$

FIG. 8: Satellite measured sea surface temperature, with geostrophic currents as arrows (6-day composites)

due to the previously mentioned upwelling, and probably largely composed of diatoms [Strub 19]. From March 26 to April 18, the biomass is much less abundant, which is also, most likely, a consequence of the relaxation of the upwelling and the coastward flows of surface waters. On April 1-6, a bloom is visible near Cucao coast, which may be related to the first recordings of red tide on the Pacific coast (see §2.3). Later in April 19-30, important blooms are again visible along all of Chiloé's Pacific and South coast, and in between the dumpings zone and the coast, consistent with the second pulse of red tide at its climax.

\section{SIMULATION OF TRANSPORT USING MERCATOR MODEL AND ARIANE}

To study the extraordinary 2016 red tide, it is necessary to analyze climatic conditions [Buschmann 16, Garreaud 18, Strub 19]. however, it is our purpose, in this paper, to assess whether this bloom could have been fueled not only by naturally occurring, upwellingenhanced nutrients, but also by the nitrogen-rich biomass of the rotting salmons. To investigate this, we use an oceanic model and simulate the transport of the pollutions.

\subsection{Surface currents in the MERCATOR model}

MERCATOR [Lellouche 16] is a global oceanic model based on self-consistent equations, which assimilates realtime data of SST, SSH, vertical in situ $\mathrm{T} / \mathrm{S}$ profiles. The atmospheric forcing (surface air temperature and humidity at height $2 \mathrm{~m}$, mean sea level pressure and wind at height $10 \mathrm{~m}$, radiative and rainfall fluxes) is taken from the ECMWF model. Then, for each time, a complex smoothing procedure including knowledge of past and future is used to finally output a complete 3D representation of the ocean. We use daily output data from the Global Sea Physical Analysis and Forecasting Product (001-024), available at http://marine.copernicus.eu/, which has 50 vertical layers, logarithmically spaced, and a horizontal grid resolution of $1 / 12^{\circ}$ (approx. 8km).

Figure 11 shows monthly averaged surface currents in MERCATOR, in the uppermost layer (depth $z=0.5 \mathrm{~m}$ ). In March, the surface current is dominated by northward currents, which is well compatible with winds and geostrophic currents presented in §3. During April, the gyre seen from the SSH data (see Fig. 4), is clearly present, and, most importantly, the coastal current is southward all along Chiloé's coast, from $41^{\circ} \mathrm{S}$, southwards. During May, a surface cyclonic gyre is present a bit further north, while the current on a wide coastal band, is southward.

Figure 12 shows daily surface currents in the MERCATOR model, for the key period for our study. These data 


\section{a)}
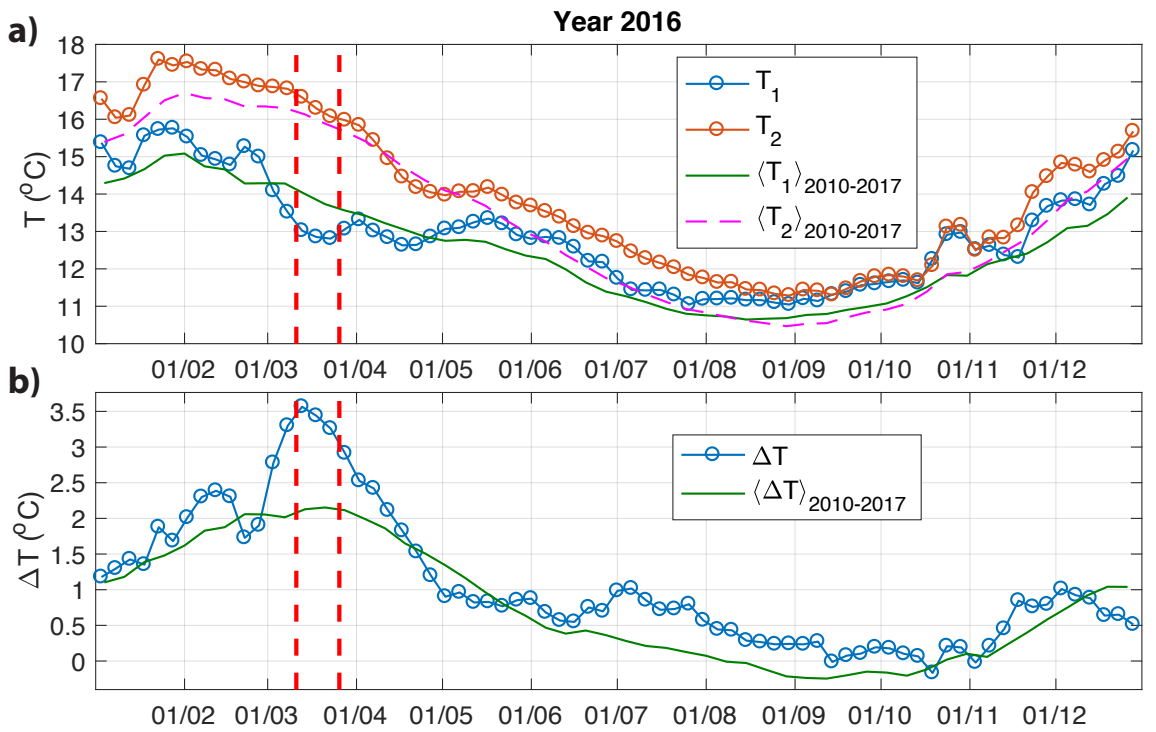

c)

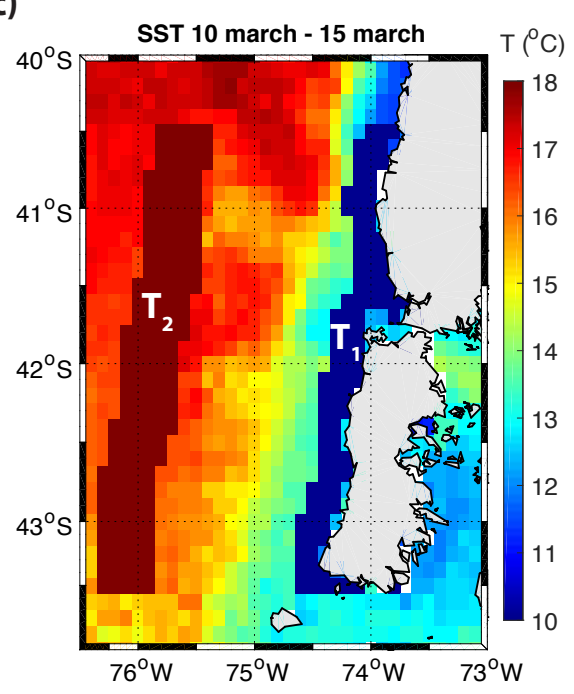

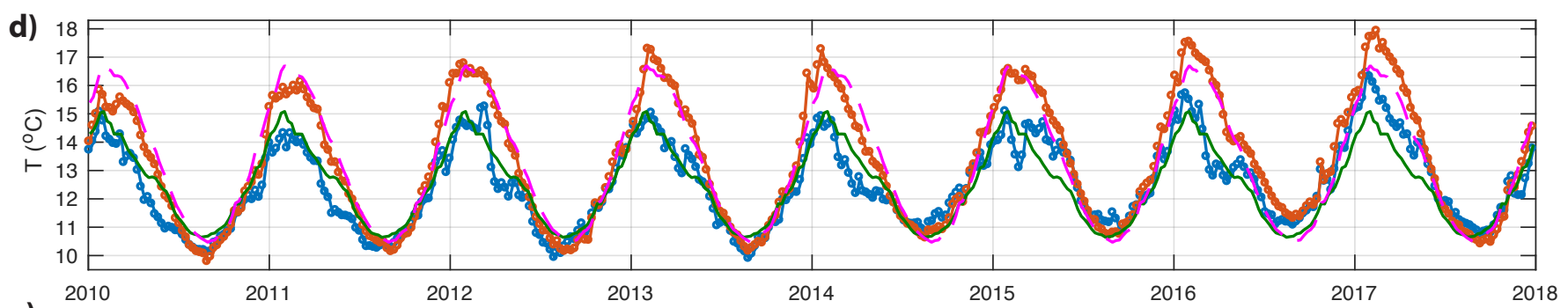

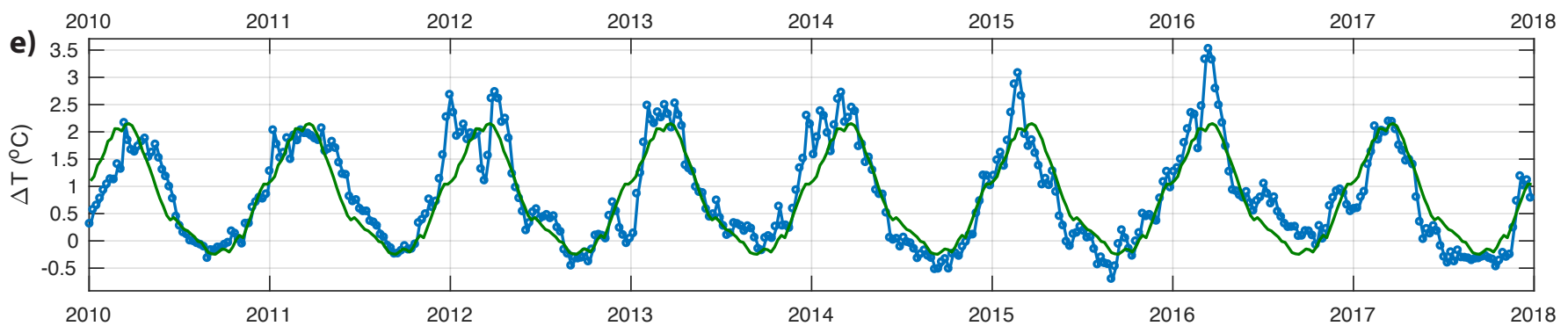

FIG. 9: Evolution in 2016 of a) surface temperatures $T_{1}$ and $T_{2}$ and b) $\Delta T=T_{2}-T_{1}$. The continuous and dashed curves represent the 2010-2017 averages in all panels. Vertical dashed lines show the dumpings period. c) SST map for March 10-15, 2016, showing the areas used to compute $T_{1}$ (in blue : distance to coast $4 \mathrm{~km}<d<24 \mathrm{~km}$ ) and $T_{2}$ (in red : $120 \mathrm{~km}<d<160$ $\mathrm{km})$. d) Evolution during 2010-2017 of $T_{1}$ and $T_{2}$ and e) of $\Delta T$.

can be compared with the measured daily winds in Fig. 6, and day-to-day correspondences can be noticed. In particular, between March 27 and 31, while wind blew southward, currents from the dumping zone bend towards the northern Chiloé coast (around $41^{\circ} 45^{\prime} \mathrm{S}, 74^{\circ} 30^{\prime} \mathrm{W}$ ). Coastward surface currents are again well visible by pulses on April 5 to 6 , April 12 to 15, again in agreement with the events of southward or eastward winds visible in Fig. 6.

During those days, these coastward surface currents have speeds $\sim 0.3 \mathrm{~m} / \mathrm{s}=26 \mathrm{~km} /$ day, meaning that a favorable wind push of 3-4 days could already bring a surface pollution substantially closer to coastal waters. Moreover, at mid-latitudes, MERCATOR is known to generally underestimate the surface currents with respect to in situ measurements, by about $20 \%$ in strong currents, to $60 \%$ in weak currents [Lellouche 16] (p. 7).

\subsection{Uncertainties in MERCATOR}

Our choice of initial conditions for the Lagrangian simulations in $\S 4.3$ strongly relies on our appreciation of the uncertainties in the modeling. Hence, we need to discuss uncertainties first. Given that the simulation is deterministic, i.e., only and fully relies on the $3 \mathrm{D}$ current data from MERCATOR, and the chosen initial conditions, the key question is to understand the uncertainties in those data. 


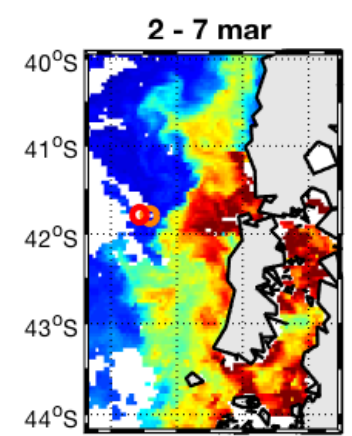

$7-12 \mathrm{abr}$
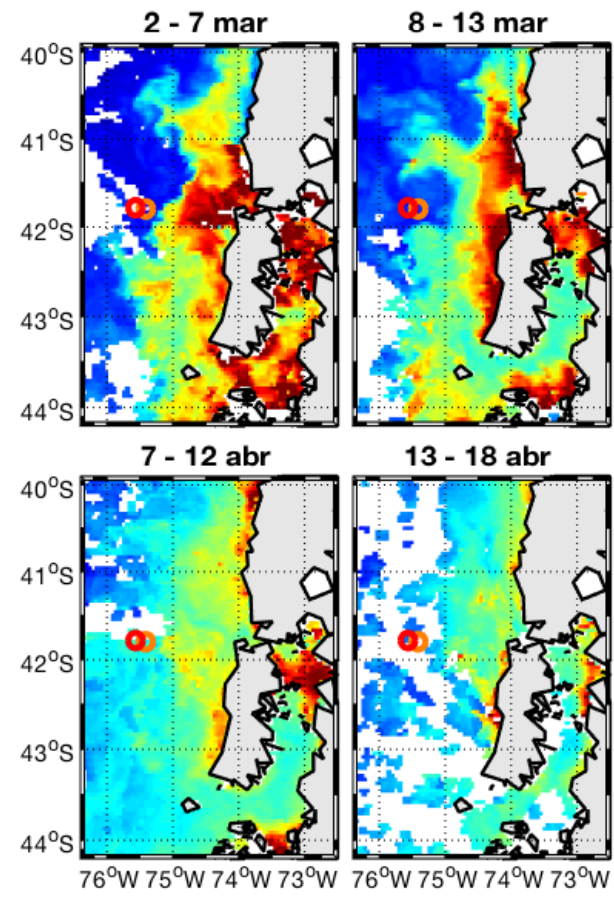

$13-18$ abr
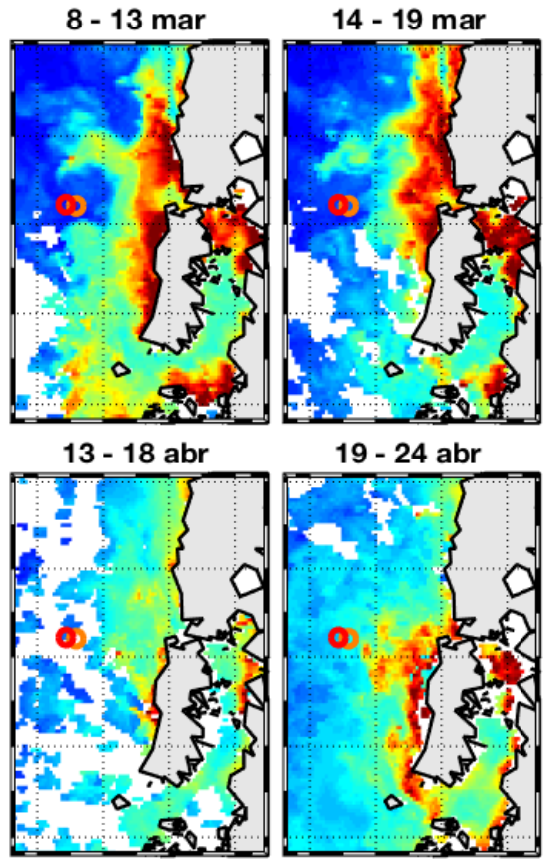

19 - 24 abr

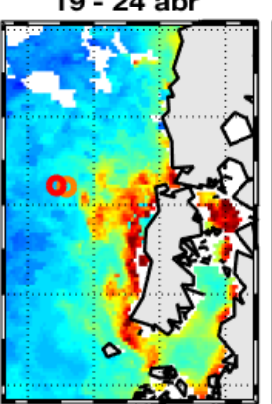

20 - 25 mar

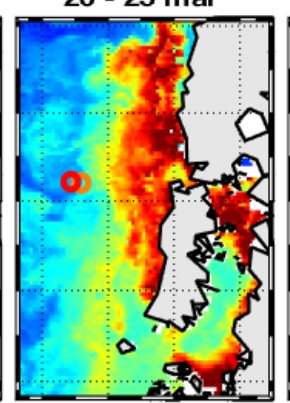

25 - 30 abr
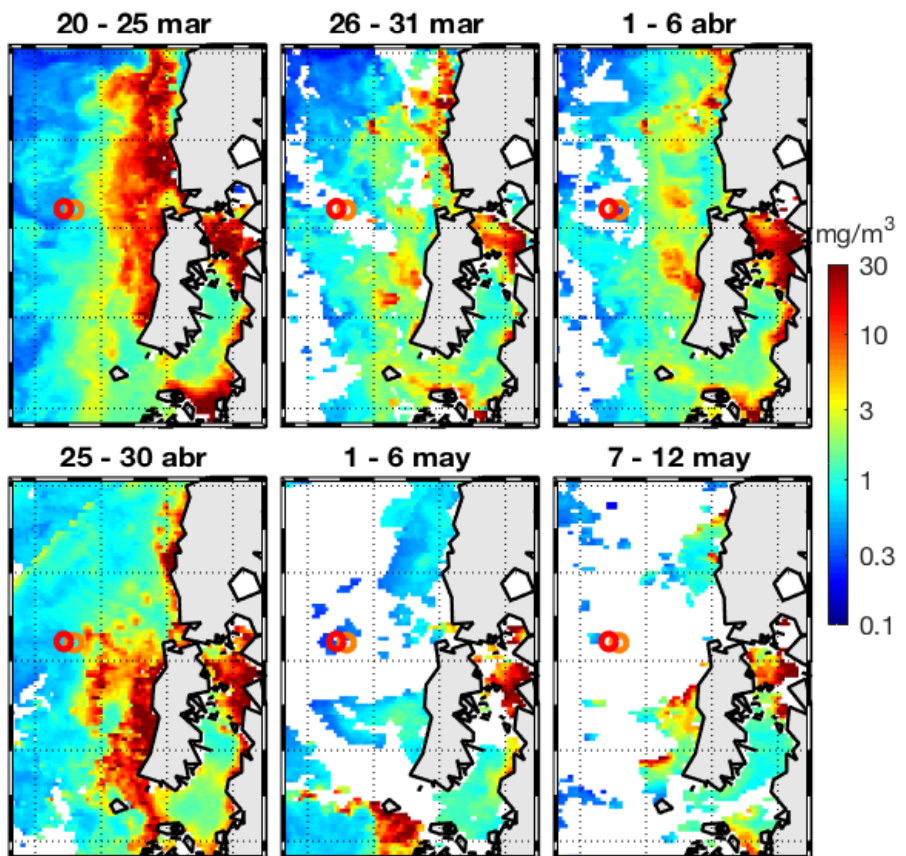

1 - 6 may

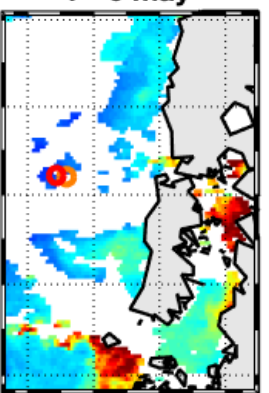

7 - 12 may

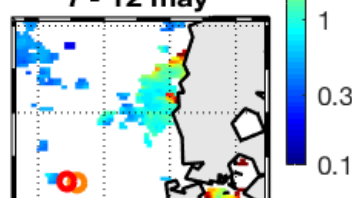

FIG. 10: Satellite (MODIS sensor) measured chlorophyll-a, at 4km resolution (6-day composites)
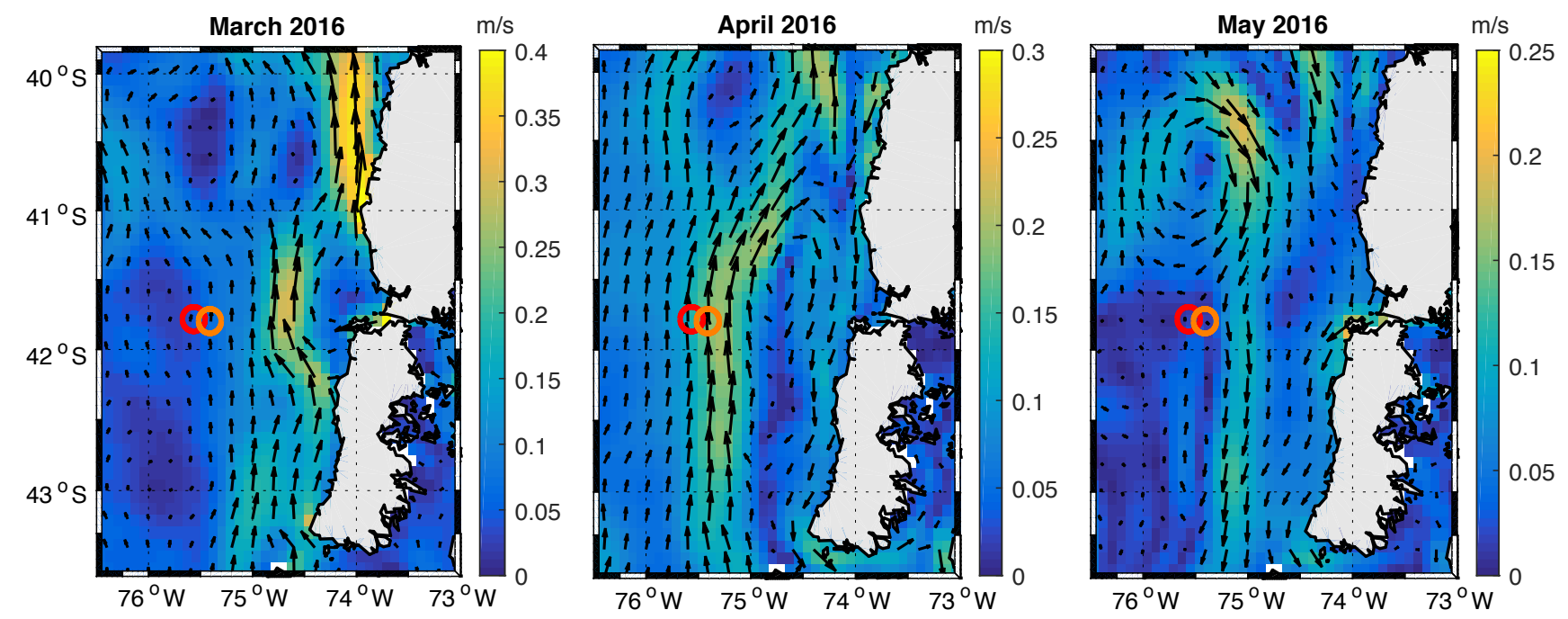

FIG. 11: Monthly averaged surface currents from MERCATOR model, in the surface layer (depth $z=0.5 \mathrm{~m}$ ).

Two sources of uncertainty and error should be considered. Firstly, the field data assimilated in MERCATOR are essentially from satellites for this region. Besides their intrinsic measurement errors, they have limited spatial resolution, typically $25-50 \mathrm{~km}$, and limited temporal resolution, typically, daily for wind data, and weekly for altimetry data. For altimetry data, the patterns are stable over several days (see Fig. 5), also due to the inertia of the non-surfacic ocean. However for wind data, which force the surface oceanic layer, and thus play a cru- cial role in driving the transport relevant for this study, the variability is considerable at the daily level and even within the daily cycle, as can be seen in Fig. 6 (see also [Aguirre 14]), and as we also see in our data sets with 6-hours resolution. Important errors can thus arise, especially in the wind data, from the interpolation and extrapolation procedures.

The second source of error comes from the modeling itself. The parameterization of several physical processes, e.g., the momentum transfer from wind to ocean and 


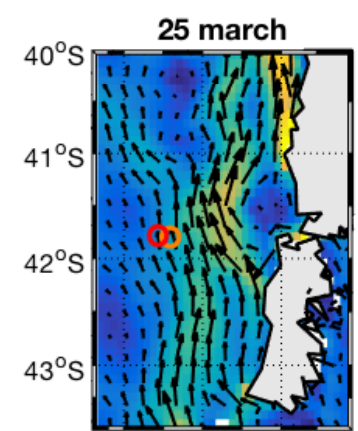

31 march

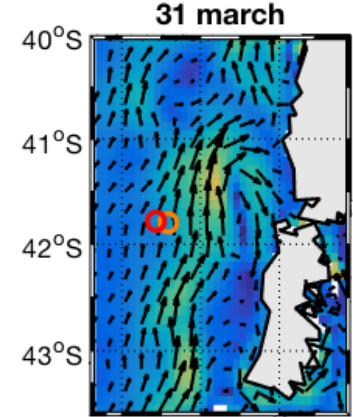

6 april

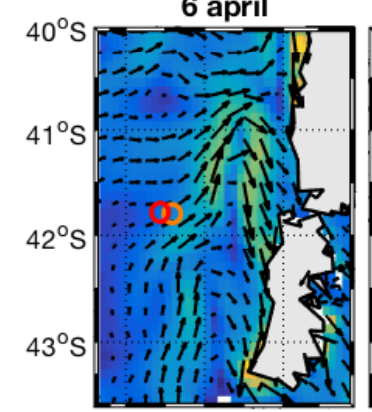

12 april

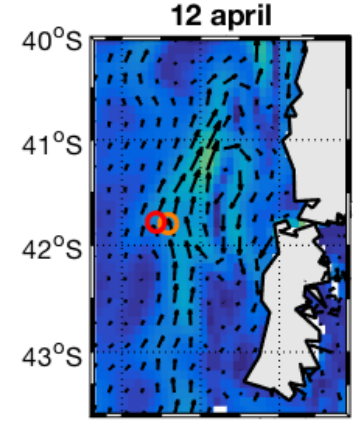

$76^{\circ} \mathrm{W} 75^{\circ} \mathrm{W} 74^{\circ} \mathrm{W}$

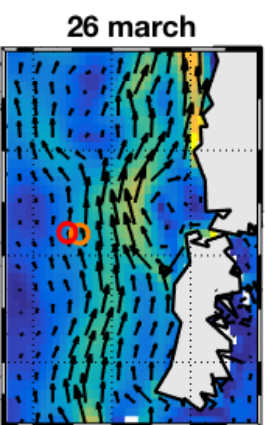

1 april

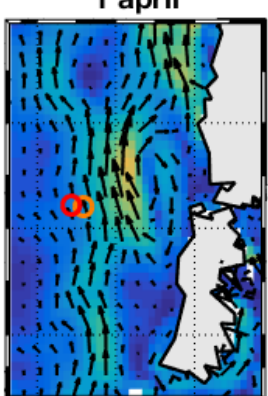

7 april

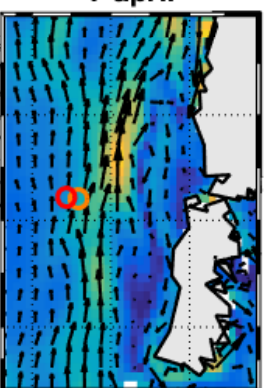

13 april

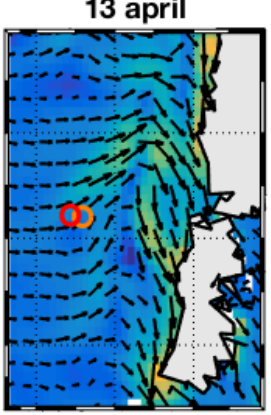

$76^{\circ} \mathrm{W} 75^{\circ} \mathrm{W} 74^{\circ} \mathrm{W}$
27 march

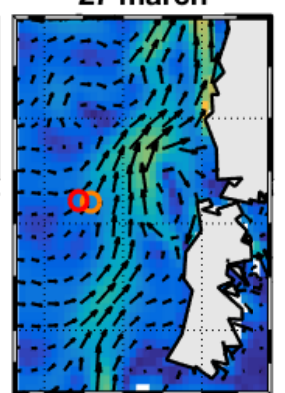

2 april

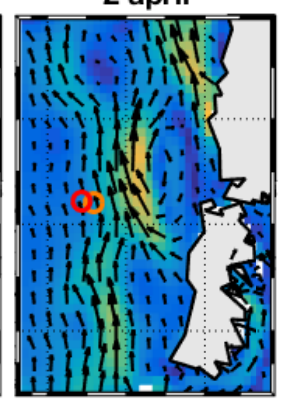

8 april

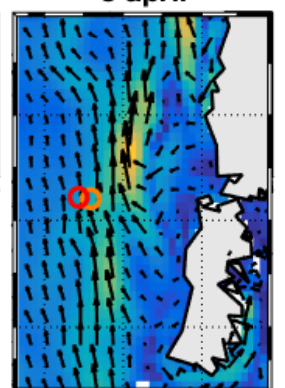

14 april

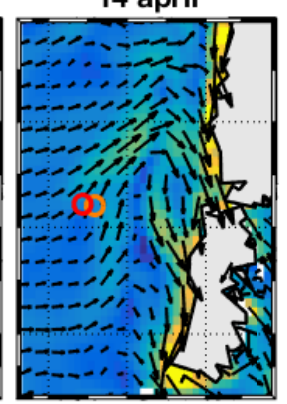

$76^{\circ} \mathrm{W} 75^{\circ} \mathrm{W} 74^{\circ} \mathrm{W}$
28 march

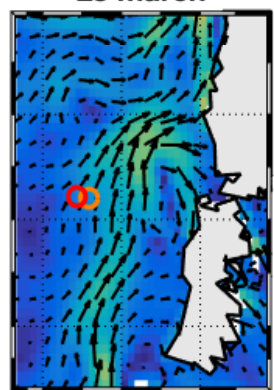

3 april

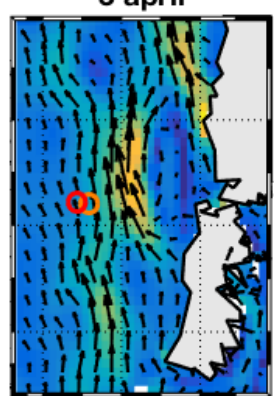

9 april

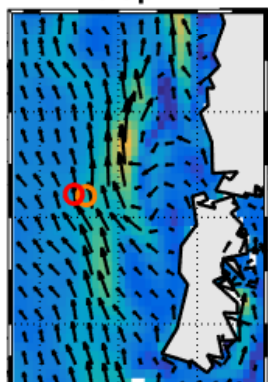

15 april

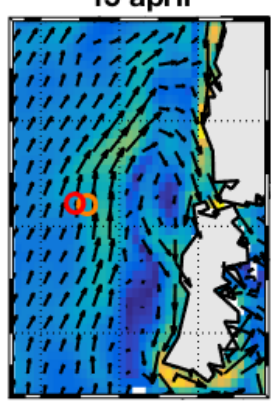

$76^{\circ} \mathrm{W} 75^{\circ} \mathrm{W} 74^{\circ} \mathrm{W}$
29 march

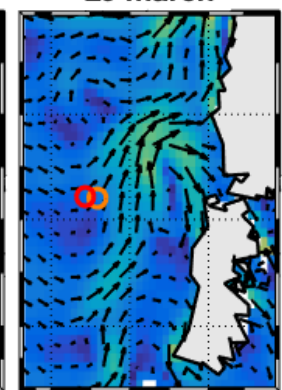

4 april

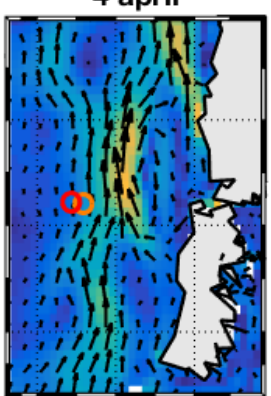

10 april

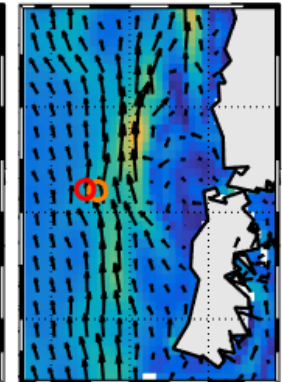

16 april

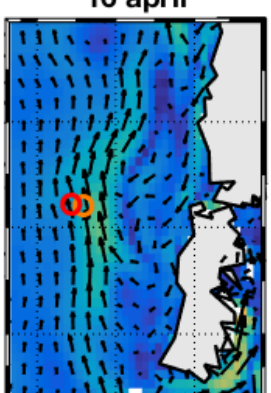

$76^{\circ} \mathrm{W} 75^{\circ} \mathrm{W} 74^{\circ} \mathrm{W}$
30 march

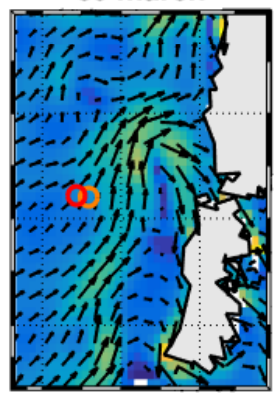

5 april

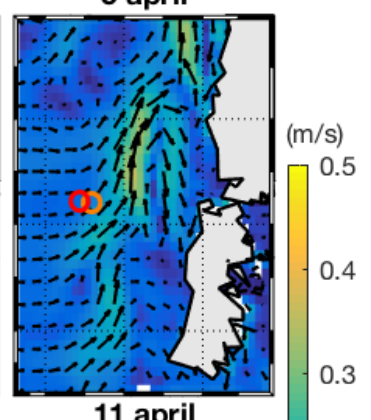

0.3

FIG. 12: Daily currents in MERCATOR model, in the surface layer (depth $0.5 \mathrm{~m}$ ).

between oceanic layers, involves uncertainties. Additionally, for self-consistency, the reanalysis has to incorporate all informations and constraints of different origins, which implies that finally it necessarily has to distort its representation even for some variables for which a direct observation is available, for example, the SSH.

Figure 13 offers an intuitive grasp on the possible discrepancies of the model with the reality, by comparing the daily SSH in MERCATOR (upper panel), with the reconstructed satellite observation (lower panel). Overall, similar general patterns are visible, in particular, the presence of the cyclonic gyre from late March through April. However, important differences are visible, in the shapes, positions, and magnitudes of the features. Discrepancies of $\sim 30 \mathrm{~km}$ are easily observed.

In summary, given the uncertainties in the original data, in the complex modeling procedure, the absence of in-situ data, and the discrepancies between the SSH 


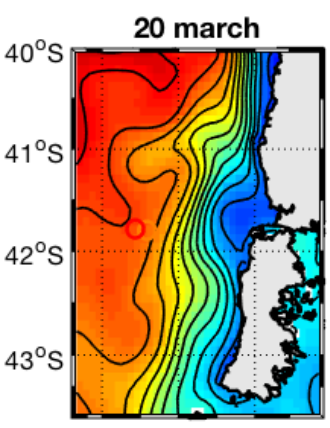

20 March

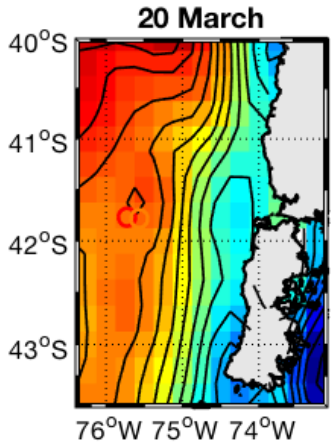

28 march

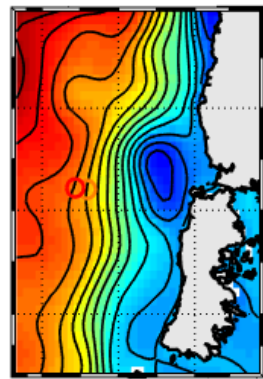

28 March

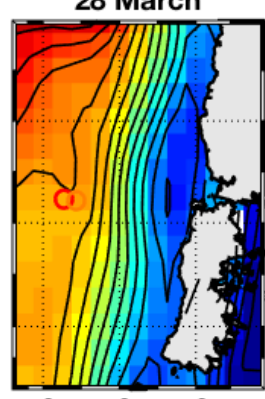

$76^{\circ} \mathrm{W} 75^{\circ} \mathrm{W} 74^{\circ} \mathrm{W}$ a) MERCATOR model
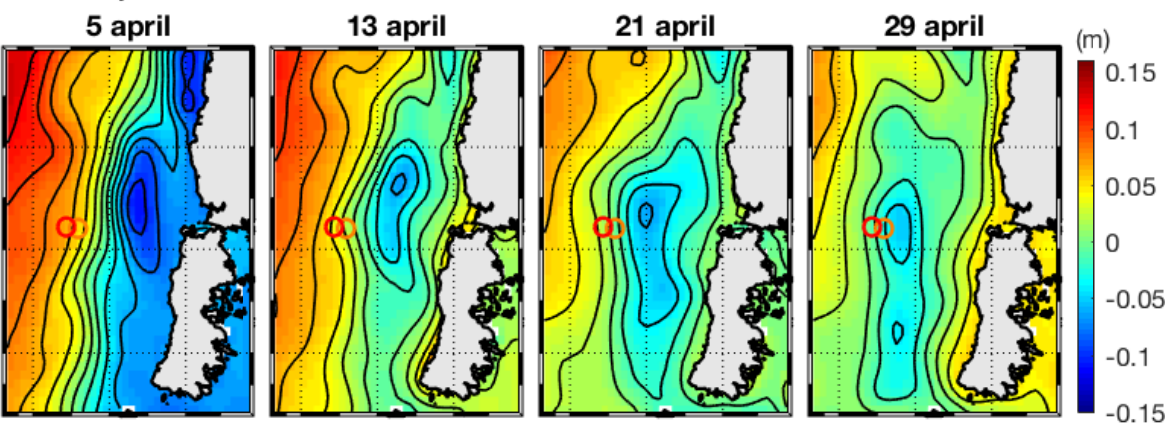

b) Satellite observation
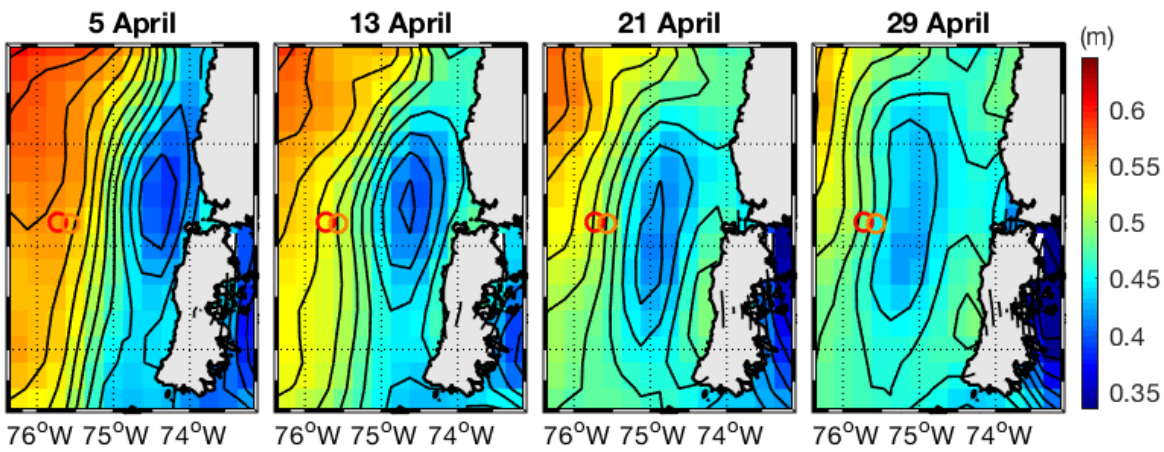

FIG. 13: Comparison of SSH in a) the Mercator model and b) satellite observations as in $\S 3.1$. Contour lines are every $2 \mathrm{~cm}$.

in the model and observed SSH, we estimate that the locations of features in the MERCATOR currents that we use below, and the computed trajectories, should be taken with a range of uncertainty of typically $\sim 30 \mathrm{~km}$.

\subsection{Transport simulations using ARIANE}

In order to obtain representations of the transport of the organic pollution after dumping, we use the MERCATOR current data to run simulations, which are completely deterministic, using the Lagrangian transport code ARIANE [Ariane 92]. We focus on the hypothesis of pollution in the surface or near surface layer, considering that the decomposing dumped material, as seen in Fig.1.a, b, c, probably includes an important liquid and dissolved fraction, given the advancement of decomposition. Indeed, in those pictures, full fish bodies are hardly distinguishable. We also assume that the high amount of fat in salmon bodies could result in floating behavior, similarly to oil spills. Fig. 1.c actually gives a strong impression of floating behavior.

Figure 14 shows simulation results as trajectories for pollutions initially placed in the upper layer of MERCATOR $\left(z_{0}=0.5 \mathrm{~m}\right)$. For each of the 8 days of dumping (see Fig. 3 for the masses dumped each day), 9 representative simulations were run simultaneously, using passive tracers initialized at midday, at different locations, the final simulation date being May 5 in all cases. For the sake of qualitative representativeness and readability, we chose initial positions at one same latitude, in the center of the official dumping zone, and regularly spaced longitudes, which cover the whole official dumping zone, but also extend Eastward to the area at 75 NM from Faro Corona (orange circle, see $\S 2.2$ ), and closer to the coast.

Two reasons motivate our choice of such range of initial positions. Firstly, the uncertainties in the knowledge of the system and the modeling, discussed above in $\S 4.2$, imply that considering strictly only the officially authorized zone would yield results that could be biased, and not reflect the full range of really possible outcomes. The second reason is the suspicions about dumpings outside the authorized zone (See $§ 5.3$ ), including one dumping officially reported outside the official zone and closer to the coast (see Fig. 3).

For dumping on March 11 to 20, Fig. 14 shows the surface pollutions being transported essentially northward, as expected from the wind and current patterns in midMarch, described in $\S 3$. However, for the latest dumpings on March 24, 25 and 26, several trajectories show possible surface transport of pollution towards the coast of Chiloé and, north of it, to Los Rios region. The trajectories noted as type A, start northward, then turn east and south by early April, very much like the cyclonic gyre presented in $\$ 3$, and at the same time as tongues of warmer water are seen flowing coastward (see circle 

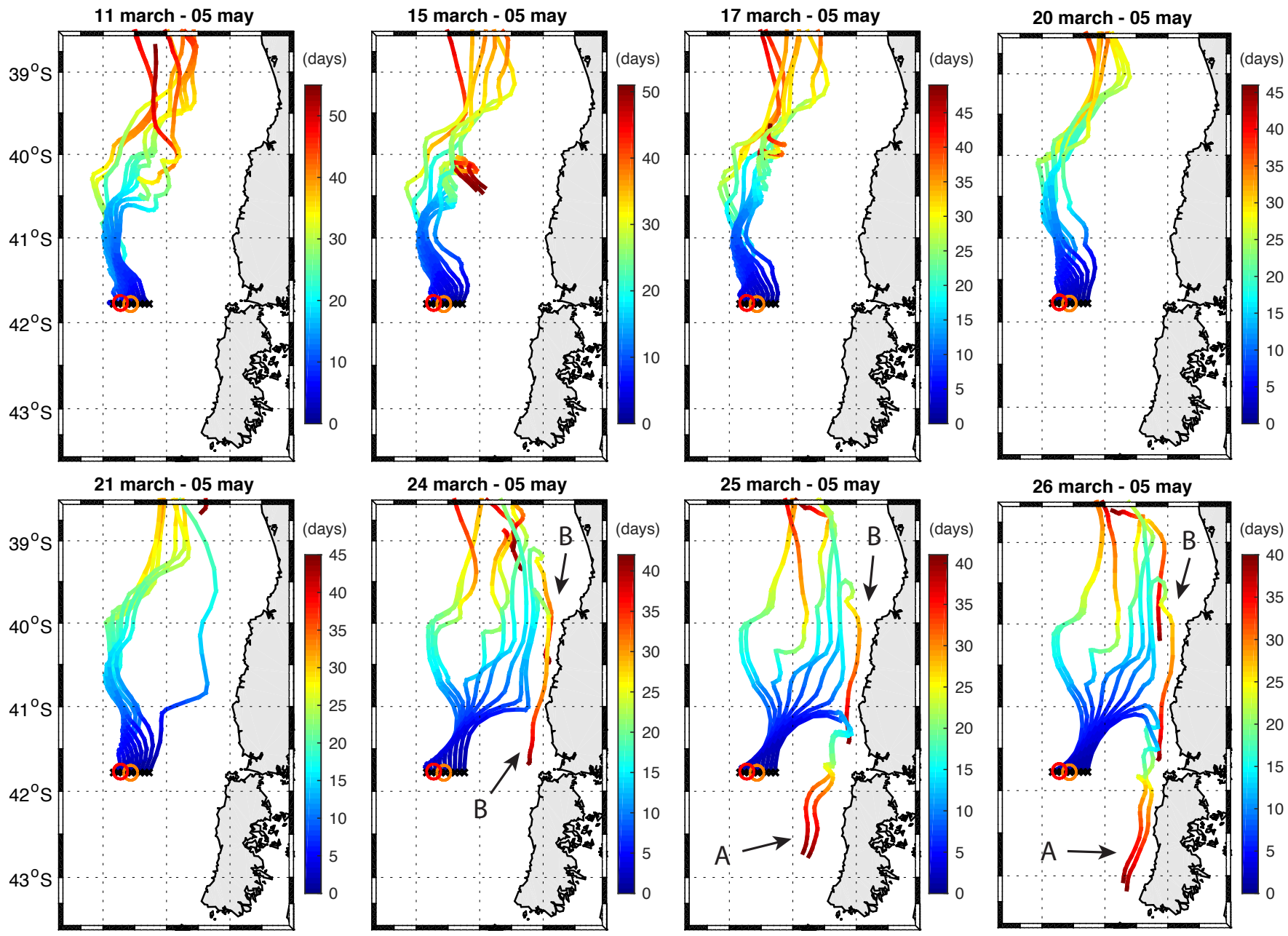

26 march - 05 may

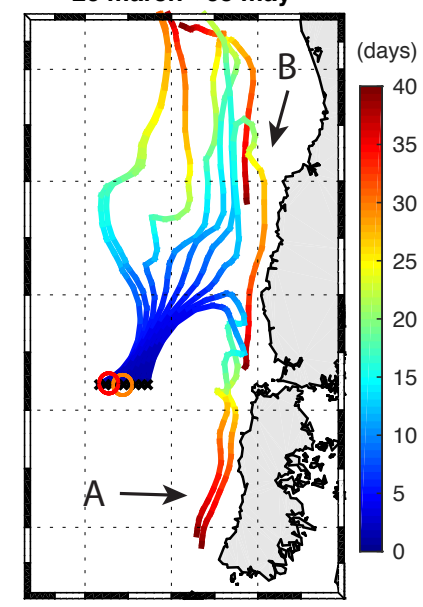

FIG. 14: Simulated trajectories of passive tracers initialized in the upper ocean layer (depth $z_{0}=0.5 \mathrm{~m}$ ) at dates 11 to 26 of March, until 05 of May, using the transport code ARIANE. Colors indicate the time after dumping. At each date 9 representative tracers are launched, at the positions marked by black crosses, every $5.8 \mathrm{~km}$

on Fig. 8). They reach the vicinity of Chiloé's Pacific coast within about 20 days, i.e., they arrive in the center area of the second pulse of red tide (see Fig. 2), near the Chacao channel, around April 15, that is, near the climax of the crisis. Note that all trajectories that reach the coast, North or South of the Chacao channel (type A or B), then continue drifting along the coast southward, as expected form the surface circulation in MERCATOR in April (see Fig. 11).

For March 25 and 26, the trajectories actually display a bifurcation behavior. The ones that drift directly to Chiloé's coast (type A) are only the two initiated closest to the coast, while the next one (type B) is directed towards the coast later and further north. With complementary runs, we identify that the critical position separating the type A and type B trajectories, is located $20.9 \mathrm{~km}$ East of the official dumping zone (and only 7.7 $\mathrm{km}$ East of the area 75NM West of Faro Corona). For initial points very close to this critical value, trajectories end up reaching the coast and the simulation aborts.

Figure 15 shows similar simulations for initial depths $z_{0}=10,30,100,300 \mathrm{~m}$, for three dumping days, and 9 initial longitudes separated by $7.4 \mathrm{~km}$, to cover a slightly wider range. For dumping on March 11, at depths $10 \mathrm{~m}$ and $30 \mathrm{~m}$, we notice that the pollution is initially transported southward, in agreement with the geostrophic current at those dates (see Fig. 5), as was also suggested in [Greenpeace 16]. However the well dominant later transport is northward, as for the surface case, except for the initial depth of $300 \mathrm{~m}$, where transport is substantially slower and returns southward after about 30 days. For dumpings on March 20 and 26, we observe analogous effects with the varying depth, and we conclude that, within the MERCATOR model, the surface behavior observed in Fig 14 with possible transport to the coast, extends to at least $10-20 \mathrm{~m}$ deep. On the other hand, for 


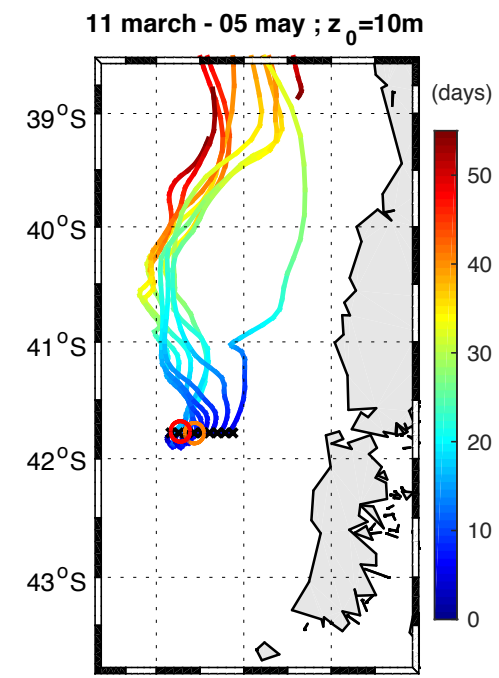

20 march - 05 may ; $z_{0}=10 m$

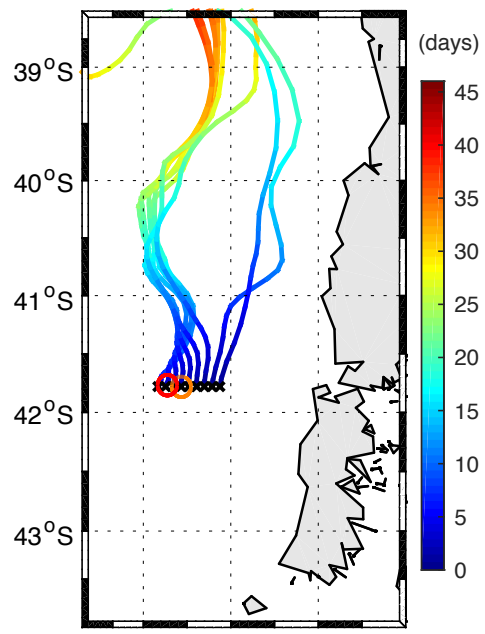

26 march - 05 may ; $z_{0}=10 \mathrm{~m}$

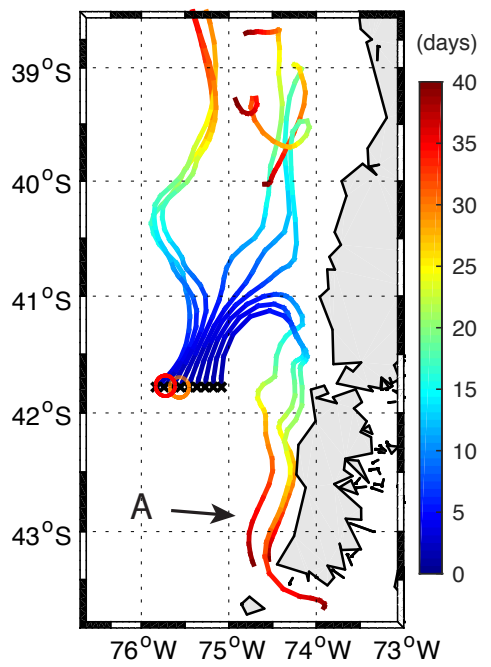

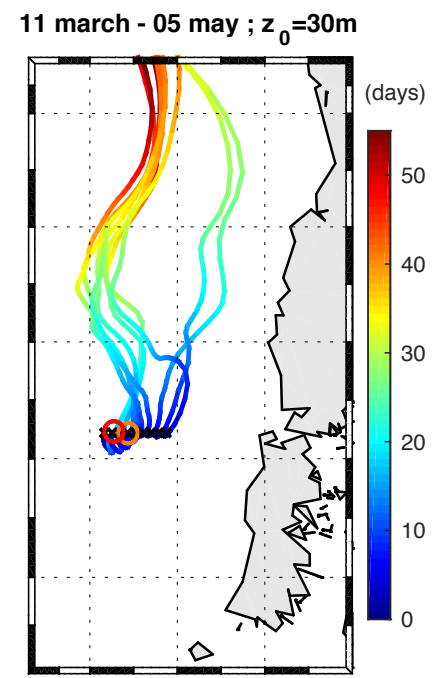

20 march -05 may ; $z_{0}=30 \mathrm{~m}$

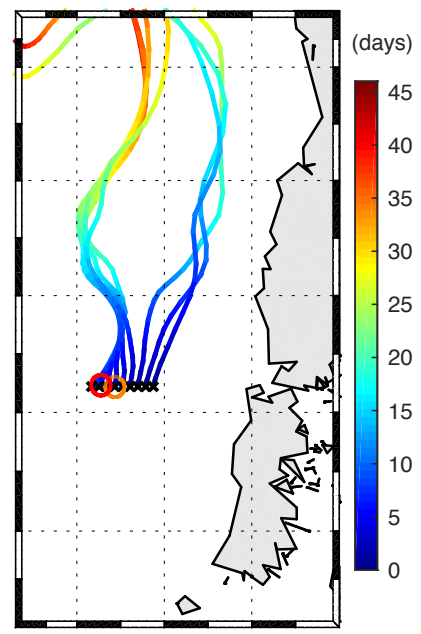

26 march -05 may ; $z_{0}=30 \mathrm{~m}$

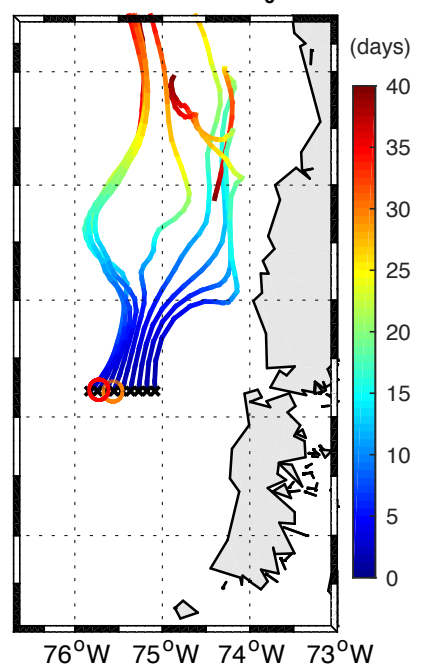

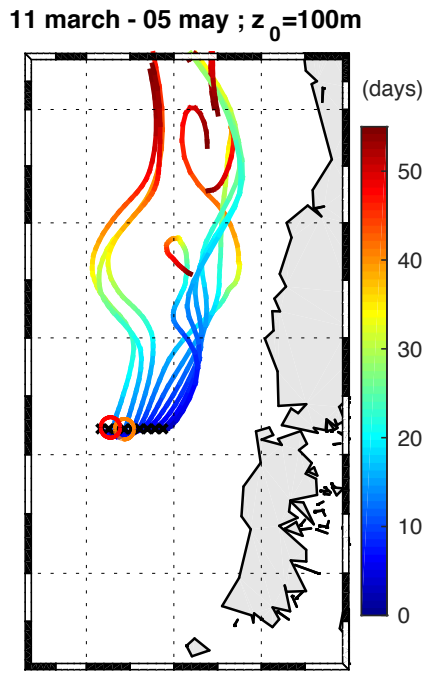

20 march -05 may ; $z_{0}=100 \mathrm{~m}$

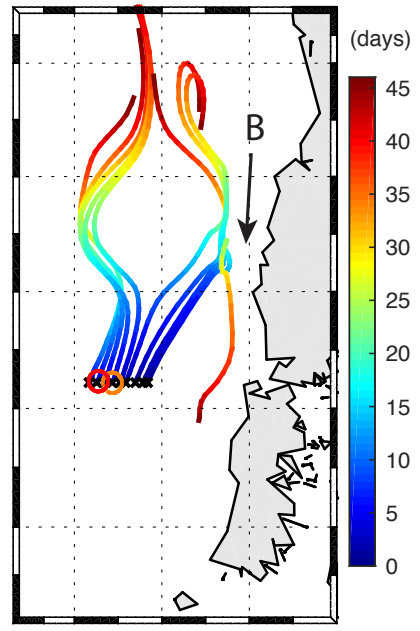

26 march -05 may ; $z_{0}=100 \mathrm{~m}$

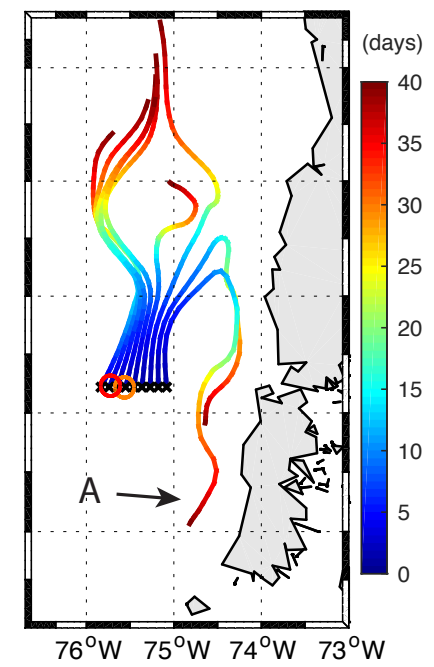

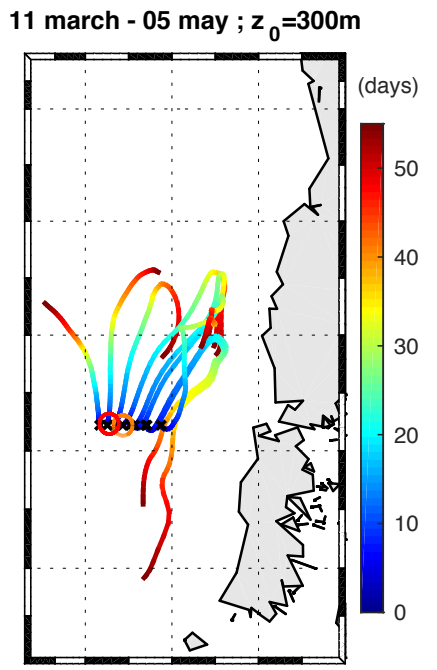

20 march - 05 may ; $z_{0}=300 m$

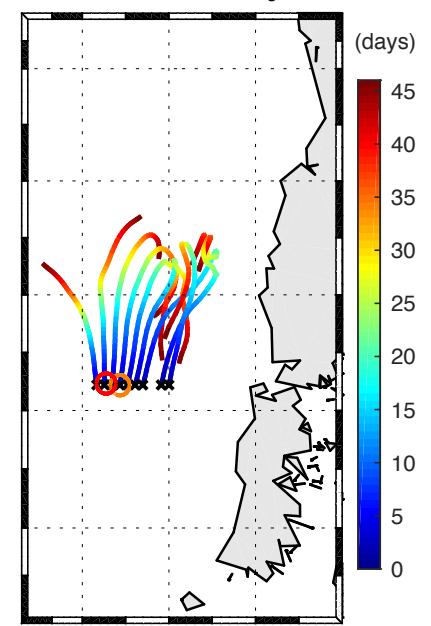

26 march - 05 may ; $z_{0}=300 m$

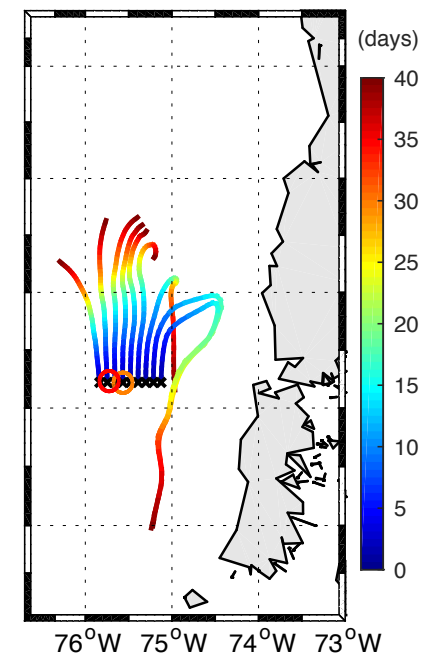

FIG. 15: Simulated trajectories of passive tracers initialized at depths $z_{0}=10,30,100,300 \mathrm{~m}$, on March 11, 20, 26, until May 5. For each simulation, 9 representative tracers are launched, at the positions marked by black crosses, every $7.4 \mathrm{~km}$ 
all initial dates, the pollutions initialized 300m deep are transported substantially slower and may return to their starting point within the month of May.

Note that, in all cases, vertical transport was weak : pollutions initialized at $300 \mathrm{~m}$ stayed between $350 \mathrm{~m}$ and $240 \mathrm{~m}$ until May 5 , and pollutions initialized at $0.5 \mathrm{~m}$ or $10 \mathrm{~m}$, stayed in the same surface layers.

\section{DISCUSSION : HOW TO EXPLAIN THE CRISIS, WHAT TO LEARN FROM IT ?}

Let us now confront the various hypotheses for the 2016 red tide crisis, and discuss the science and regulations around it.

\subsection{Possible fueling of the red tide by the pollution}

\subsubsection{The $\mathrm{NH}_{4}^{+}$patches and their possible origin from the dumpings}

In late May 2016, the scientific commission called by the government navigated on the scientific navy ship Cabo de Hornos, and measured several parameters along two transects in the Pacific, one meridional, one zonal, and one in the CIS (see Fig. 16). The most intriguing result was the finding of three large patches of dissolved ammonium $\left(\mathrm{NH}_{4}^{+}\right)$. The first patch (Fig. 16.d) was detected during the zonal transect, on westernmost station S8, near the authorized dumping zone. With maximal concentrations around $0.3 \mu \mathrm{M}$, it extended from the surface to at least $250 \mathrm{~m}$ deep. The second patch (Fig. 16.c), reaching higher concentrations of about $1.2 \mu \mathrm{M}$, was found at station S9, very near Chiloé's coast, in surface waters (depths $<30 \mathrm{~m}$ ). Important concentrations above $0.8 \mu \mathrm{M}$, were found also on the S10 neighboring station, and above $0.4 \mu \mathrm{M}$ in surface waters of the northernmost stations S1 and S2. Given the very low spatial resolution of the data, it is clear that the reconstructed map bears large uncertainties. Even though, it seems that this coastal patch may have extended 50-80 $\mathrm{km}$ along Chiloé's coast. A third patch with concentration above $1 \mu \mathrm{M}$ was found in the last station $\mathrm{S} 15$, at the entrance of the Reloncavi Sound.

The presence of $\mathrm{NH}_{4}^{+}$in such important concentrations is very intriguing. Generally, $\mathrm{NH}_{4}^{+}$is the form of $\mathrm{N}$ most rapidly consumed by phytoplankton, thus, it cannot last very long in the euphotic layer, and such large $\mathrm{NH}_{4}^{+}$patches have to come necessarily from a recent, massive amount of decomposing biomass [Buschmann 16]. Concerning the offshore patch at $\mathrm{S} 8$, the commission concluded that it very probably originated from the dumped salmons. However, for the coastal patch in S9, they mentioned only vaguely two hypotheses : the "mortality and decomposition of marine fauna", or the "unsupervised discharge of organic material" (p. 46). The patch in $\mathrm{S} 15$, being in a rather enclosed area, close to many aquaculture centers and to Puerto Montt, is less surprizing.

According to [Buschmann 16], the decomposition of salmon is expected to result rapidly in a large mass of $\mathrm{NH}_{4}^{+}$. Since about $3 \%$ of the body mass of salmons is $\mathrm{N}$ [Larkin 97], the decomposition of 5,000 tons of dead animals should yield about 190 tons of $\mathrm{NH}_{4}^{+}$(not 1,700 tons, as stated in [Buschmann 16]). Considering, as a rough estimate, a concentration of $0.8 \mu \mathrm{M}$, over a patch of $20 \mathrm{~km} \times 10 \mathrm{~km}$, extending $10 \mathrm{~m}$ deep, the mass of $\mathrm{NH}_{4}^{+}$in the coastal patch would be 29 tons, which corresponds to about $15 \%$ of the total $\mathrm{NH}_{4}^{+}$produced by the dumping, i.e., to about the $\mathrm{NH}_{4}^{+}$from 1-2 days of dumping.

In terms of transport, our simulations in Fig. 14 show that this patch could very well originate from the dumping, in particular, with trajectories of type B. To test this hypothesis, we perform backward i.e., time-reversed simulations, which is straightforward with ARIANE. Figure 17 shows the results for pollutions initialized on May 28 off Cucao, at constant longitude $74.4^{\circ} \mathrm{W}$ and 7 latitudes from $42.81^{\circ} \mathrm{S}$ to $42.43^{\circ} \mathrm{S}$, spaced every $6.9 \mathrm{~km}$, at initial depths $z_{0}=2 \mathrm{~m}$ and $6 \mathrm{~m}$. Strikingly, for the $2 \mathrm{~m}$ deep pollution, the backward trajectories travel first coastward, then northward for about 40 days, then return southward and finally take a westward turn, passing, on March 25 and 26 , less than $20 \mathrm{~km}$ from the edges of the authorized dumping site, with all trajectories remaining very closely together during the 70 days of drift. The pollution initialized at $6 \mathrm{~m}$ depth follows similar but more sparse trajectories. Note that it was not possible to initialize our simulations closer to the coast due to recurring "coast crash" errors.

It is thus a very relevant scenario, that the $\mathrm{NH}_{4}^{+}$surface patch in Fig. 16.c, comes from the dumped salmons. If true, this would show that a substantial fraction of the organic pollution floated, and remained in surface waters for at least several weeks. And thus, it makes it all the more likely, that other fragments of the pollution could have followed surfacic trajectories of type A (see Fig. 14), and thus been brought near the Chacao channel and Chiloé's coast, more directly and within only 15-20 days, i.e., by early and mid-April.

\subsubsection{Why $\mathrm{NH}_{4}^{+}$pulses could strongly favor an A. catenella bloom}

Several reasons make patches of decomposed proteic matter, and especially $\mathrm{NH}_{4}^{+}$, very favorable fuels for red tides. Firstly, it is known that "when systems are more enriched with chemically reduced $\mathrm{N}$ forms", that is, organic forms, especially, $\mathrm{NH}_{4}^{+}$and urea $\left(\mathrm{CO}\left(\mathrm{NH}_{2}\right)_{2}\right)$, "the resulting communities are often dominated by mixotrophic dinoflagellates or (pico)cyanobacteria as well as bacteria" [Glibert 16]. Additionally, as noted in 
a)

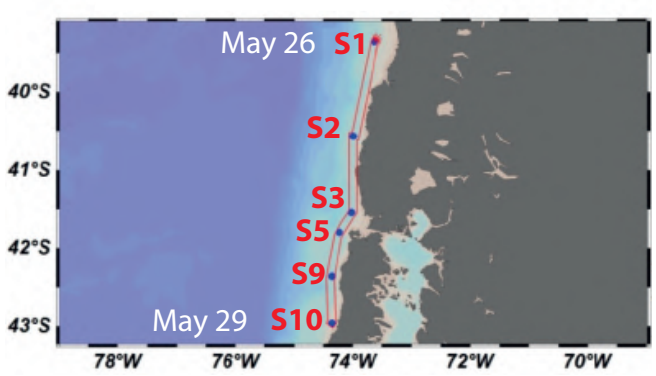

c)

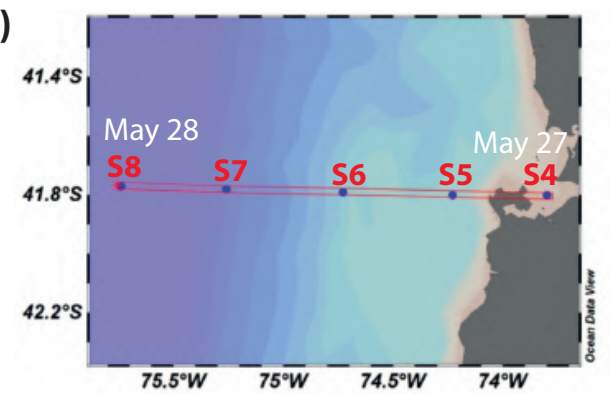

e)

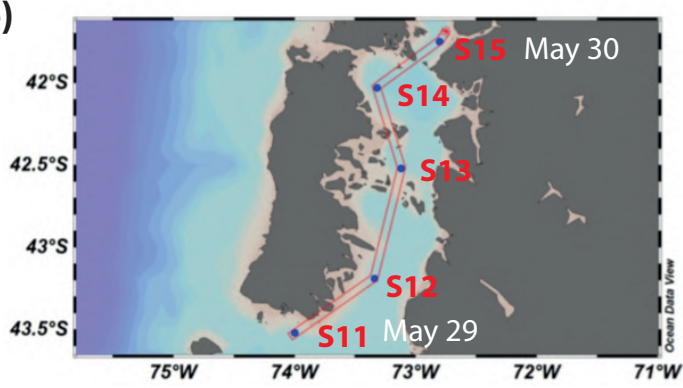

b)
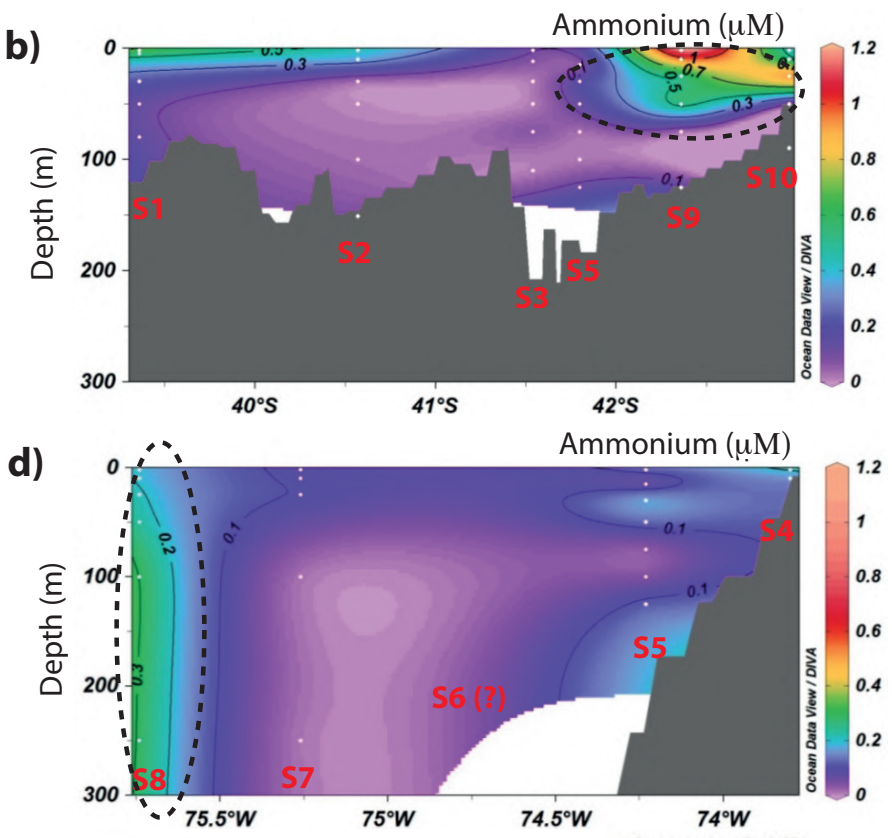

f)

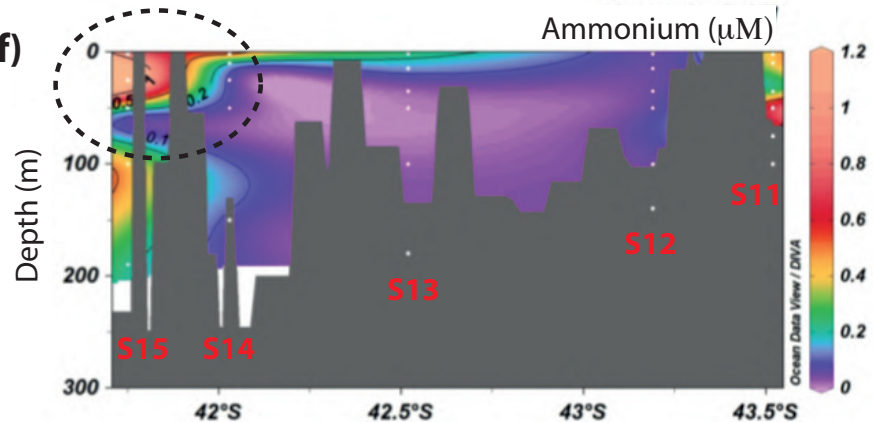

FIG. 16: The three ammonium anomalies found in [Buschmann 16]. a, c, e) : Transects along which the ocean was measured. b, d, f) : Ammonium profiles. White dots show the measurements positions. Full maps obtained using Ocean Data View.

[Glibert 11], many HAB species are excellent competitors for nutrients under non-Redfieldian conditions. In particular, when the ratio $\mathrm{N} / \mathrm{P}$ is high, they can uptake a lot of excess $\mathrm{N}$, especially $\mathrm{NH}_{4}^{+}$, to produce more toxicity, as is shown in Fig. 6 of [Glibert 11], for Alexandrium tamarense, also a PST producer.

Besides such abilities to use excess organic N, it is relevant that, in nutrient-rich conditions, many harmful algal species including $A$. catenella, are mixotrophic, i.e., "they can phagocyte other microorganism that are more abundant in the eutrophic conditions [Burkholder 08]" [Glibert 11]. Moreover, mixotrophic dinoflagellates can ingest "a wide variety of different prey items, including bacteria, other algae and protists, and fish tissue" [Glibert 11], and an additional advantage of $A$. catenella is that is is a rapidly moving organism, able to swim $10-20 \mathrm{~m} /$ day to find nutrients.

Within the species complex A. tamarense [John 14], which includes the ecotype A. fundyense (Group I), named A. catenella in Chile, the ecotype A. pacificum
(Group IV), also displaying PSP toxicity, was studied in the Thau lagoon area (Mediterranean) [Collos 09], showing that it grows mostly on reduced forms of $\mathrm{N}: \mathrm{NH}_{4}^{+}$or urea. Additionally, laboratory studies (e.g. [Laabir 11] for A. pacificum and [Avila 15] for A. catenella) have shown these species to be rather robust and flexible with regards to physical parameters (temperature, salinity, irradiance), therefore the availability of nutrients appears a key factor controlling bloom growth.

Last but not least, [Buschmann 06] reported in vitro experiments showing a 50-fold enhancement of the abundance of dinoflagellates in seawater containing Chilean salmon farm effluents, which are rich in urea and $\mathrm{NH}_{4}^{+}$, compared to regular seawater (see their Fig. 5, noting that sublabels $\mathrm{B}$ and $\mathrm{C}$ are inverted in the caption [Buschmann 19]), as well as an in vivo observation of a strong pulse of dinoflagellates (up to 700 cells $/ \mathrm{mL}$, i.e., level 6 in the scale of Fig. 2), near a newly installed salmon farm in the Reloncavi Sound shortly after its installation, compared to two control sites located $1.5 \mathrm{~km}$ 


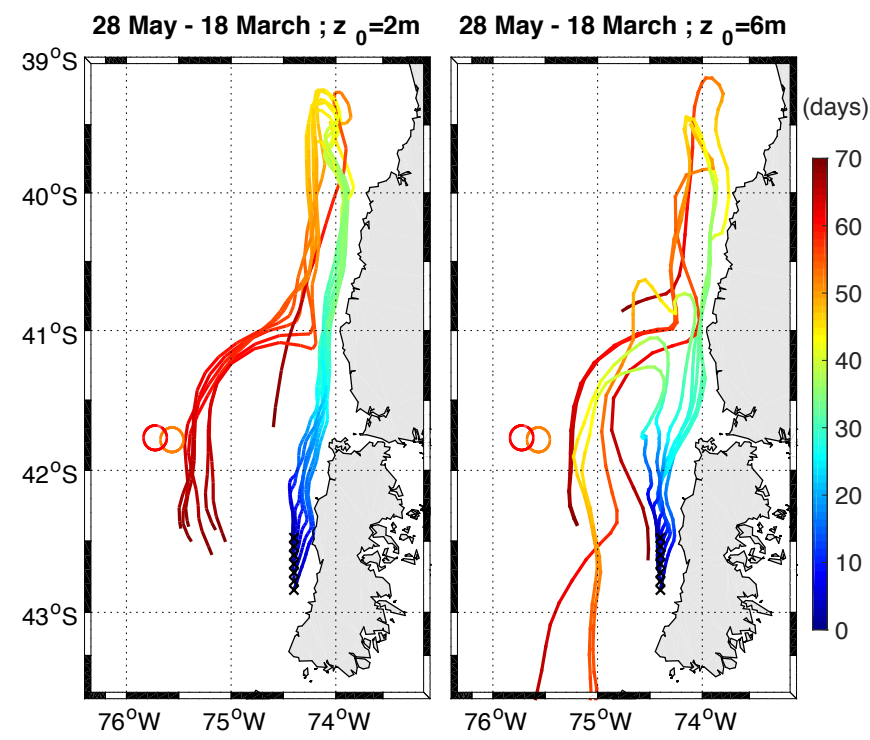

FIG. 17: Backward simulations of transport from near the found costal $\mathrm{NH}_{4}^{+}$patch, at depths $z_{0}=2 \mathrm{~m}$ and $6 \mathrm{~m}$, from May 28 to March 18. Black crosses mark the 7 initial positions, spaced every $6.9 \mathrm{~km}$.

away from the farm. Unfortunately, to our best knowledge, such impressive pioneering observations were not followed by more such studies in Chile, even though they strongly suggested that salmon farm effluents can greatly enhance the populations of dinoflagellates, potentially harmful.

As seen above, besides the natural driving factors of physical oceanography, especially water column stratification, and cyst bed dynamics, that have been shown to control A. catenella blooms in the Gulf of Maine [McGillicuddy Jr 05] and Tasmania [Condie 19], multiple evidence in literature indicates that the decomposed salmon biomass, with abundant $\mathrm{NH}_{4}^{+}$, possibly residual fish tissue, and other biomass of microorganisms, all available in the photic zone, had an a priori strong potential to fuel the red tide, possibly enhancing both its extension, and toxicity.

\subsection{Critical overview of previous works}

Let us now discuss the previously proposed explanations for the second pulse of the red tide.

\subsubsection{The Red Tide Commission report}

Called by the Chilean government in the heat of the crisis, the scientific commission produced an extensive report [Buschmann 16], including mostly analysis based on remote satellite sensing, and some limited field data, acquired in late May. Their explanation for the bloom is based on transport of seeding cells by northward winds from the Aysén region, and fueling by upwelling. Concerning the dead salmon pollution, they conclude that transport occurred towards West and North, and not towards the island of Chiloé (p 53).

In their analysis of winds, they say that "zonal wind was very weak during the summer 2016, and anomalously negative [...] from April-May 2016" (p. 22). As we see on Fig. 7.c, in the relevant period of March until April 22 , on the contrary, zonal wind was positive, blowing towards the coast. The conclusion of transport mostly towards West and North, is thus surprising and doubtful in our perspective. Our simulations (see Fig. 14) also never showed westward transport.

Concerning geostrophic currents, the report only presents one figure (Fig. 14), for March 13-20. Since the dumpings lasted from March 11 until March 26, and then drifted for several weeks, it seems very insufficient to use such a reduced window of analysis. In particular, this truncated window omits the cyclonic gyre, which was prominent from the last days of dumping, until the detection of the second pulse of the red tide (see Fig. 5). Therefore, the conclusions of [Buschmann 16] about the transport of the salmon pollution, are in our view, not sufficiently grounded.

\subsubsection{The Greenpeace report}

Also launched in the heat of the crisis, an investigation carried by Greenpeace [Greenpeace 16] attempted to understand the red tide and the role of the dumpings. In this work, the geostrophic currents were analyzed only from March 11 to 20, and neither until the end of dumpings, nor after them, and the main conclusion was that currents could have brought pollutions southward. This effect can indeed be seen in our simulations on Fig. 15, for the dumping on March 11, and depths $z_{0}=10 \mathrm{~m}$ and $30 \mathrm{~m}$, for the westernmost initial points, but only for the first 5 days or so of simulation, after which, transport is northward. The Greenpeace report also stated that the pollution might have reached the coast, and fueled the bloom, so that an influence could not be excluded. We agree on this general conclusion, but, as for [Buschmann 16], the transport analysis for the pollution seems not well framed.

\subsubsection{Papers studying only climatic factors}

Several later works have proposed climatic explanations to the red tide. At the International Conference on Harmful Algae (ICHA 17), held in Florianopolis, SC, Brazil, on November 2016, a round table was organized about Chile events, but only the paper [Clément 16] ad- 
dressed the catastrophic $\mathrm{HAB}$ crisis, and was presented by authors from the major consulting firm working for the salmon industry (Plancton Andino). The paper studies climatic factors, addressing only the fish-killing Pseudochattonella bloom (brown tide), and does not mention the salmon dumpings. The 2016 red tide was thus essentially absent from the papers at ICHA 17.

Later [Garreaud 18] analyzed large scale climatic features of the summer 2016 in northern Patagonia, to propose explanations for several anomalous events, among which, the two major HAB events. Concerning the red tide (A. catenella bloom), this study puts forward the strong northward winds in the summer, and the upwelling episodes, which are described as notably anomalous relative to a long term climatological series (1950-2016).

More recently, [Strub 19] analyzed in detail the climatic conditions offshore Chiloé, considering a shorter reference time frame (1993-2016). This work also proposed that sustained northward winds in February and March could have transported A catenella cells from further south, and brought abundant nutrients by upwelling in the photic zone. They note however, that neither the meridional wind anomaly in summer 2016, nor the strong upwelling, were exceptional (see §3.3). In their Fig 10, one sees that the northward episodes of early 2016 were only moderately anomalous. Further, [Strub 19] describe a strong wind relaxation in late April and May, which could have caused favorable conditions for the red tide. In our Fig. 6 and Fig. 7, we see moderately lower wind intensities starting after April 20, but, in the records, the second pulse of the red tide peaked around April 13-21 (see Fig. 2). Thus, the wind relaxation, which is not very marked, may arrive too late to explain the outburst of the red tide.

Finaly, [Trainer 19] have discussed the 2016 HAB events in Chile, attributing entirely the causality of the Alexandrium catenella bloom to exceptional El Niño oceanic conditions. Regarding the hypothesis of a possible fueling by the salmon pollution, they consider that [Buschmann 16] have proven, including by "modeling", that "prevailing currents transported the nutrients released to the west and north, and not towards Chiloé Island". From our arguments presented in §5.2.1, such interpretation is highly disputable, in particular because the analysis of geostrophic currents in [Buschmann 16] is temporally insufficient, and no quantitative modeling of transport is realized.

In sum, we see is that the jury is still out, i.e., both climatic factors, and fueling by the salmon pollution, need to be considered as possible explaining factors for the 2016 extraordinary bloom of $A$. catenella .

\subsection{Lack of science and mismanagement of risk}

The scientific debate around the extraordinary 2016 red tide crisis took place in the midst of strong pressure from civil society, confronting the giant fishery and aquaculture industry. Whether and how science and regulations can be independent and objective when they touch to large economic interests, is probably a wide open question. As a last stage in this paper, we overview the halo of deficiencies in science and regulations which have surrounded the whole crisis.

\subsubsection{Mismanagement of mortalities in 2016}

Firstly, the industry was not prepared to the massive salmon mortalities experienced in the summer 2016. During this crisis, following reports by Sernapesca, the SMA (subsecretary of environment) condemned two companies for their mismanagement of the mortalities in centers where the totality of fish had died : Salmones Maullin which lost 2,400 and 2,100 tons in two centers in the western Reloncavi Sound and Autralis Mar which lost 1,170 tons near Calbuco in the Northwestern CIS. Those companies had taken more than the extraordinarily allowed 20 days to remove the rotting animals from the cages : by March 13, Australis Mar still had 406 tons in the water, and 202 tons by March 21, while on March 16 Salmones Maullin had still not removed 337 tons from the center Isla Huar (rotting since 23 days) and on March 14, 735 tons from the center Maillen, that were found in decomposing state [SMA 16a, SMA 16b]. This causes risks to the environment and the workers, due to the release of lethal sulphuric acid, a possible eutrophication pulse, and other risks [SMA 16a, SMA 16b]. Further doubts have also been raised on the complete reporting of the mortalities in all affected centers.

Later, several sources said that chemicals accompanied the decomposing animals, as e.g., the Mayor of Ancud [INDH 16]. Many informal reports have also denounced illegal dumpings outside the official zone, and several such testimonies were collected in the report by the $\mathrm{Hu}$ man Rights National Institute [INDH 16], for example by the neighbors syndicate (JJVV) of Carelmapu.

But the most striking lack of studies, happened in the decision of the dumpings. Asked on March 3, the dumpings were authorized on March 4 [Sernapesca 16b], without any accompanying study or modeling being disclosed. Given that the climatological average wind in the area is coastward year round, as can be seen, e.g., in Fig. 8 of [Strub 19], the decision was intrinsically hazardous. Besides, the dumping was carried during a strong upwelling event (see $\S 4.3$ ), with an important amount of chlorophyl present offshore waters (see Fig. 10). Considering additionally that in 2009 A. catenella cells had reached the area [Mardones 10], and that the red tide was recently 
present on the southern coast of Chiloé and in Aysén, the risk of an extension of the first pulse of the red tide further North was present [Greenpeace 16, Strub 19]

The dumping itself violated the London protocol, due to insufficient studies, which was the main reason for the condemnation by the Supreme Court [CorteSuprema 18]. During and after the dumping, no monitoring took place, at all. The chemical composition of the dumped material was not even characterized, as stated in [Sernapesca 16a] (§4): "the treatment to the mortalities has not been investigated". The same document recommended (§5.1) that, "before eliminating the organic material, it should be mixed with water" as well as other surprizing ideas like "realizing the disposal in pulses of time", in order to "reduce its buoyancy", although clearly, neither mixing with water or discharging by pulses would change the density of the dumped material. It was also recommended to monitor the buoyancy of the material, but nothing was reported on this matter, raising further doubts and concerns.

Finally, the official institutions maintained thoughout the crisis, an a priori bias to attribute the whole crisis to climatic factors, as in [Sernapesca 16c] : "these phenomena [the two $2016 \mathrm{HABs}$ ] occurred due to regional climatic and oceanographic conditions, with water temperatures 2 or 3 degrees above the norm", and completely dismissed the possible influence of the pollutions.

\subsubsection{Deficiencies in studies : a hazardous future}

Given the pressure put on the Patagonian aquatic ecosystem by the salmon and aquaculture industries, the very low input of basic science to back regulations is alarming. The expansion northwards of A. catenella, from the southern tip of the country, where it was first detected in 1972 [Guzmán 75, Guzmán 02, Varela 12], is a major and growing ecological and socio-economic issue in Chile, which may even hold a world record in PSP toxicity, since in February 2018, a toxicity reaching 140,000 $\mu \mathrm{g}$ STX/100g of mollusc flesh, was measured in the Aysén region [Verdejo 18].

But the 2016 red tide crisis is not the only striking recent ecological catastrophe having taken place in Chilean Patagonian waters. Several strange massive mortality events have been reported, especially in 2016 [Sernapesca 16c, Sernapesca 17], some related to ecological imbalances and/or possibly red tides. In March 2015, the largest ever baleen whale mortality was recorded, and attributed to a bloom of $A$. catenella [Häussermann 17]. On April 7, 2016, the arrival of an estimated 9,000 tons of dead sardins [Sernapesca 16c] in the estuary of Queule (Araucania region), remains unexplained. Our simulations show that this mortality might also be related to the second pulse of the 2016 red tide, especially for dumpings in early March (see Fig. 14), which drifted mostly North- wards, and could have reached Queule by early April.

Many works dealing with red tide issues and the ecological impacts of aquaculture in southern Chile, have identified an ever-urgent need for more science, and science-based regulation [Arzul 01, Buschmann 09, Buschmann 16]. However, monitoring is still very limited, and regional oceanographic modeling is still under construction. Strikingly, although nutrient enrichment from fish farms, [Buschmann 06], and the related risks of eutrophication and impacts on the benthic life, such as dramatic boosting on the abundance of dinoflagellates [Buschmann 06], anaerobic sediments routinely reported by the industry (e.g., in 757 reports out of 4488 during 2010-2018 [Sernapesca 18]), biodiversity collapse [Soto 04], and azoic conditions [Mulsow 06], are relatively well documented in certain specific locations and studies, the patterns of eutrophication have never been systematically assessed at the region scale.

In the near future, the Chilean salmon industry plans to almost double its production, expanding mostly in the southernmost and still most pristine Magallanes region, where the salmon production already rose from 10,000 ton to 100,000 ton in 8 years [CORFO 17]. In the context of accelerating climate change, where $A$. catenella has been suggested as a possible "resilient winner" [Mardones 16], and with increasing ecological perturbations and multiplying HAB threats, the lack of regulation and science, including in the understanding of the socio-ecological systems [Mascareño 18], sets a very dangerous frame for the Chilean patagonian oceanic ecosystems and communities.

\section{CONCLUSION}

The 2016 red tide crisis was one of the major socioenvironmental crisis in Chilean history, but has not been well explained, and might never completely be. Called in emergency during the crisis, the scientific commission [Buschmann 16] discarded the influence of the mass oceanic dumping of rotting salmons, while the Greenpeace report [Greenpeace 16] made the opposite claim. Later academic studies addressed climatic factors, dwelling on two features of the summer 2016 : the strong northward winds, and the related upwelling episodes. While those two anomalies certainly played a role, we saw that they are not extraordinary for this area. In our work, we focussed on two anomalies fully unique of 2016, but so far omitted in the peer-reviewed works : the dumping of rotting salmons, and the latter finding of the coastal and oceanic $\mathrm{NH}_{4}^{+}$patches.

Our analysis shows consistently that the dumping could well have played a fueling role for the second pulse of the red tide. The mesoscale circulation displayed a robust cyclonic gyre (Figs. 4 and 5), and the wind off Chiloé, had several southward and eastward episodes 
in late March and April (Figs. 6 and 7), well able to cause downwelling, which is confirmed by the SST data, which displays coastward progressing tongues of offshore warmer water (Fig. 8) and a strong decay of the upwelling temperature difference from mid March to late April (Fig. 9). The MERCATOR oceanic model indeed shows surface currents in late March and April, able to generate coastward paths (Fig. 11 and 12), and our simulations display short (type A) or longer (type B) coastward paths, both in surface (Fig. 14) and in near surface layers (Fig 15).

Our simulations actually yield rapid, type A trajectories of pollutions towards Chiloé only if they start more than $20.9 \mathrm{~km}$ off the authorized dumping zone. However, given the uncertainty range in the complex MERCATOR modeling (Fig. 13), described in $\S 4.2$, it is very possible that part of the pollution, mostly from the last days of March 24-26, was carried to the coast of Chiloe and the Chacao channel within 10-20 days, by early and midApril, that is, near the climax of the second pulse of the red tide (Fig. 2). In particular, given the known systematic underestimating by $20-60 \%$ in MERCATOR of wind-driven surface transport [Lellouche 16], the 4-5 days pulse of southward wind in late March, could have pushed patches of pollution closer inside the geostrophic gyre, facilitating further coastward transport. Other parts of the pollution, following type B trajectories, could have reached the coast further North, and then drifted along the coast southward, explaining well the $\mathrm{NH}_{4}^{+}$patch found in late May (Fig 16). On the other hand, denser parts of the pollution, could have slowly sunk at the dumping location, and explain the $\mathrm{NH}_{4}^{+}$patch found there.

Given the rapid tendency of proteic matter to form $\mathrm{NH}_{4}^{+}$, and the known ability of decomposing organic matter, and especially $\mathrm{NH}_{4}^{+}$, to favor mixotrophic dinoflagellates, it is thus a quite reasonable hypothesis, that transported pollution could have substantially fueled the second pulse of the red tide. This bloom could have started offshore, and have become very toxic even before hitting the coast, which would explain the sudden massive deaths on Pacific beaches. It could have been seeded by vegetative cells transported form the earlier southern bloom (first pulse of the red tide), as suggested in [Buschmann 16] and [Strub 19], or, alternatively, by resting cysts near Chiloé remnants of the 2009 episode, brought up by upwelling, or even, by offshore populations of A. catenella [Mardones 19]. The hypothesis of red tides seeded by offshore cyst banks in Pacific shelf sediments has been suggested by several authors [Mardones 10, Díaz 14, Díaz 18], but cyst banks in Pacific Chilean waters have never yet been detected. There is however no available public data to evaluate any of these hypotheses. On the other hand, the hundreds of tons of rotting salmons, sometimes left illegally more than three weeks in the cages $(\S 5.3 .1)$ in the northwestern CIS and near the very tidally active Chacao Channel that connects subdaily the northern CIS and Pacific waters, could also have contributed to discharge pulses of $\mathrm{NH}_{4}^{+}$and have stimulated the red tide.

Besides explaining very well the finding of the coastal $\mathrm{NH}_{4}^{+}$patch, for which no other explanation has been proposed, a fueling of the red tide by the dumped salmon biomass, could help understand its explosiveness and impressive toxicity, including the observed massive mortalities of costal organisms.

Whereas a full understanding of this red tide is out of reach, due to an almost complete lack of in situ data, we thus conclude that the salmon dumpings cannot be excluded as a possible fueling source for the extraordinary bloom. We also note that science and regulation concerning the Chilean Patagonian ocean, its ecology, and the impacts of aquaculture, are still highly deficient, so that a strong effort for public and independent science, and science-based regulation, is still an urgent necessity to protect the region from future crisis.

We acknowledge Tarsicio Antezana, Jorge Mardones, Don Anderson, Patricia Glibert, Alejandro Buschmann, Sandor Mulsow, Hector Kol, Benjamín Suárez, Víctor Contreras, and Paulina Möller for stimulating discussions, Leonardo Guzmán and Oscar Espinoza for advices and for providing IFOP data, Estefanía González, Mauricio Ceballos and Greenpeace Chile for helps and discussions, and Nicolas Grima for assistance on Ariane. J.A. acknowledges support from FONDECYT grant 3150587.

* Corresponding author: julienarmijo@gmail.com

[Aguirre 14] C. Aguirre, R. D. Garreaud et J. A. Rutllant, Surface ocean response to synoptic-scale variability in wind stress and heat fluxes off south-central Chile. Dynamics of Atmospheres and Oceans 65, 64 (2014).

[Ariane 92] Ariane, What is Ariane (1992).

[Artal 19] O. Artal, O. Pizarro et H. H. Sepúlveda, The impact of spring-neap tidal-stream cycles in tidal energy assessments in the Chilean Inland Sea. Renewable Energy 139, 496 (2019).

[Arzul 01] G. Arzul, Aquaculture management and ecological interaction of noxius phytopl ankton developments in the south of Latin America. AQUATOXSAL : Summary of the final report 1 (2001).

[Avila 15] M. Avila, C. De Zarate, A. Clement, P. Carbonell et F. Pérez, Efecto de factores abióticos en el crecimiento vegetativo de Alexandrium catenella proveniente de quistes en laboratorio. Revista de biología marina y oceanografía 50, 177 (2015).

[Bentamy 12] A. Bentamy et D. C. Fillon, Gridded surface wind fields from Metop/ASCAT measurements. International journal of remote sensing 33, 1729 (2012).

[Bouwman 13a] A. F. Bouwman, A. Beusen, C. Overbeek, D. Bureau, M. Pawlowski et P. Glibert, Hindcasts and future projections of global inland and coastal nitrogen and phosphorus loads due to finfish aquaculture. Reviews 
in Fisheries Science 21, 112 (2013).

[Bouwman 13b] L. Bouwman, A. Beusen, P. M. Glibert, C. Overbeek, M. Pawlowski, J. Herrera, S. Mulsow, R. Yu et M. Zhou, Mariculture: significant and expanding cause of coastal nutrient enrichment. Environmental Research Letters 8, 044026 (2013).

[Burkholder 08] J. M. Burkholder, P. M. Glibert et H. M. Skelton, Mixotrophy, a major mode of nutrition for harmful algal species in eutrophic waters. Harmful algae 8, 77 (2008).

[Buschmann 06] A. H. Buschmann, V. A. Riquelme, M. C. Hernández-González, D. Varela, J. E. Jiménez, L. A. Henríquez, P. A. Vergara, R. Guíñez et L. Filún, A review of the impacts of salmonid farming on marine coastal ecosystems in the southeast Pacific. ICES Journal of Marine Science: Journal du Conseil 63, 1338 (2006).

[Buschmann 09] A. H. Buschmann, F. Cabello, K. Young, J. Carvajal, D. A. Varela et L. Henríquez, Salmon aquaculture and coastal ecosystem health in Chile: analysis of regulations, environmental impacts and bioremediation systems. Ocean \& Coastal Management 52, 243 (2009).

[Buschmann 16] A. Buschmann, L. Farías, F. Tapia, D. Varela et M. Vásquez, INFORME FINAL Comisión Marea Roja. (2016).

[Buschmann 19] A. Buschmann,. Private communication (2019).

[Clément 16] A. Clément, F. Muñoz, C. G. Brito, N. Correa, M. Saldivia, C. Fernández, F. Pérez, C. P. Maluje, G. Contreras et O. Egenau, Climatic anomalies and harmful flagellate blooms in Southern Chile. MARINE AND FRESH-WATER HARMFUL ALGAE 34 (2016).

[Collos 09] Y. Collos, B. Bec, C. Jauzein, E. Abadie, T. Laugier, J. Lautier, A. Pastoureaud, P. Souchu et A. Vaquer, Oligotrophication and emergence of picocyanobacteria and a toxic dinoflagellate in Thau lagoon, southern France. Journal of Sea Research 61, $68(2009)$.

[Condie 19] S. A. Condie, E. C. Oliver et G. M. Hallegraeff, Environmental drivers of unprecedented Alexandrium catenella dinoflagellate blooms off eastern Tasmania, 2012-2018. Harmful Algae 87, 101628 (2019).

[CORFO 17] CORFO, Concurso Strategic Tecnological Programs : "Tecnological Consorcium for Oceanic Aquiculture" (2017).

[CorteSuprema 18] CorteSuprema, tercera Sala, Causa 34.594-2017 (2018).

[Díaz 14] P. A. Díaz, C. Molinet, M. Seguel, M. Díaz, G. Labra et R. I. Figueroa, Coupling planktonic and benthic shifts during a bloom of Alexandrium catenella in southern Chile: Implications for bloom dynamics and recurrence. Harmful algae 40, 9 (2014).

[Díaz 18] P. A. Díaz, C. Molinet, M. Seguel, M. Díaz, G. Labra et R. I. Figueroa, Species diversity and abundance of dinoflagellate resting cysts seven months after a bloom of Alexandrium catenella in two contrasting coastal systems of the Chilean Inland Sea. European Journal of Phycology 1 (2018).

[Directemar 16] Directemar, Informe Técnico 002/2016 : Supervisión sobre vertimiento de desechos de salmones (2016).

[Folke 94] C. Folke, N. Kautsky et M. Troell, The costs of eutrophication from salmon farming: implications for policy. Journal of environmental management 40, 173
(1994).

[Garreaud 18] R. Garreaud, Record-breaking climate anomalies lead to severe drought and environmental disruption in western Patagonia in 2016. Climate Research 74, 217 (2018).

[Glibert 11] P. M. Glibert et J. M. Burkholder, Harmful algal blooms and eutrophication: "strategies" for nutrient uptake and growth outside the Redfield comfort zone. Chinese Journal of Oceanology and Limnology 29, 724 (2011).

[Glibert 16] P. M. Glibert, F. P. Wilkerson, R. C. Dugdale, J. A. Raven, C. L. Dupont, P. R. Leavitt, A. E. Parker, J. M. Burkholder et T. M. Kana, Pluses and minuses of ammonium and nitrate uptake and assimilation by phytoplankton and implications for productivity and community composition, with emphasis on nitrogen-enriched conditions. Limnology and Oceanography 61, 165 (2016).

[Greenpeace 16] Greenpeace, Reporte Crisis Social Ambiental en Chiloé. Resumen Ejecutivo Sept. 2016 (2016).

[Guzmán 02] L. Guzmán, H. Pacheco, G. Pizarro et C. Alarcón, Alexandrium catenella y veneno paralizante de los mariscos en Chile. Floraciones algales nocivas en el cono sur americano 235 (2002).

[Guzmán 75] L. Guzmán, I. Campodónico et J. Hermosilla, Estudios sobre un florecimiento tŮxico causado por Gonyaulax catenella en Magallanes. I. Distribución espacial y temporal de G. catenella. Anales del Instituto de la Patagonia 173 (1975).

[Häussermann 17] V. Häussermann, C. S. Gutstein, M. Bedington, D. Cassis, C. Olavarria, A. C. Dale, A. M. Valenzuela-Toro, M. J. Perez-Alvarez, H. H. Sepúlveda, K. M. McConnellet al., Largest baleen whale mass mortality during strong El Niño event is likely related to harmful toxic algal bloom. PeerJ 5, e3123 (2017).

[Hernández 16] C. Hernández, P. Díaz, C. Molinet et M. Seguel, Exceptional climate anomalies and northwards expansion of paralytic shellfish poisoning outbreaks in southern Chile. Harmful Algae News 54, 1 (2016).

[INDH 16] INDH, INFORME MISIîN DE OBSERVACION SITUACION SOCIOAMBIENTAL REGION DE LOS LAGOS (2016).

[Iriarte 07] J. Iriarte, H. González, K. Liu, C. Rivas et C. Valenzuela, Spatial and temporal variability of chlorophyll and primary productivity in surface waters of southern Chile (41.5-43 S). Estuarine, Coastal and Shelf Science 74, 471 (2007).

[John 14] U. John, R. W. Litaker, M. Montresor, S. Murray, M. L. Brosnahan et D. M. Anderson, Formal revision of the Alexandrium tamarense species complex (Dinophyceae) taxonomy: the introduction of five species with emphasis on molecular-based (rDNA) classification. Protist 165, 779 (2014).

[Laabir 11] M. Laabir, C. Jauzein, B. Genovesi, E. Masseret, D. Grzebyk, P. Cecchi, A. Vaquer, Y. Perrin et Y. Collos, Influence of temperature, salinity and irradiance on the growth and cell yield of the harmful red tide dinoflagellate Alexandrium catenella colonizing Mediterranean waters. Journal of plankton research 33, 1550 (2011).

[Larkin 97] G. A. Larkin et P. A. Slaney, Implications of trends in marine-derived nutrient influx to south coastal British Columbia salmonid production. Fisheries 22, 16 
(1997).

[Lellouche 16] J.-M. Lellouche, O. Legalloudec, C. Regnier, B. Levier, E. Greiner et M. Drevillon, Quality information document for Global Sea Physical Analysis and Forecasting Product GLOBAL-ANALYSIS-FORECAST-PHY-001-024 (2016).

[León-Muñoz 18] J. León-Muñoz, M. A. Urbina, R. Garreaud et J. L. Iriarte, Hydroclimatic conditions trigger record harmful algal bloom in western Patagonia (summer 2016). Scientific Reports 8, 1330 (2018).

[Mardones 10] J. Mardones, A. Clément, X. Rojas et C. Aparicio, Alexandrium catenella during 2009 in Chilean waters, and recent expansion to coastal ocean. Harmful Algae News 41, 8 (2010).

[Mardones 16] J. I. Mardones, M. N. Müller et G. M. Hallegraeff, Toxic dinoflagellate blooms of Alexandrium catenella in Chilean fjords: a resilient winner from climate change. ICES Journal of Marine Science: Journal du Conseil fsw164 (2016).

[Mardones 19] J. Mardones,. Private communication (2019).

[Mascareño 18] A. Mascareño, R. Cordero, G. Azócar, M. Billi, P. A. Henríquez et G. Ruz, Controversies in social-ecological systems: lessons from a major red tide crisis on Chiloe Island, Chile. Ecology and Society 23, (2018).

[McGillicuddy Jr 05] D. McGillicuddy Jr, D. M. Anderson, D. R. Lynch et D. W. Townsend, Mechanisms regulating large-scale seasonal fluctuations in Alexandrium fundyense populations in the Gulf of Maine: results from a physical-biological model. Deep Sea Research Part II: Topical Studies in Oceanography 52, 2698 (2005).

[Mulsow 06] S. Mulsow, Y. Krieger et R. Kennedy, Sediment profile imaging (SPI) and micro-electrode technologies in impact assessment studies: example from two fjords in Southern Chile used for fish farming. Journal of Marine Systems 62, 152 (2006).

[Pegliasco 15] C. Pegliasco, A. Chaigneau et R. Morrow, Main eddy vertical structures observed in the four major Eastern Boundary Upwelling Systems. Journal of Geophysical Research: Oceans 120, 6008 (2015).

[Pitcher 10] G. Pitcher, F. Figueiras, B. Hickey et M. Moita, The physical oceanography of upwelling systems and the development of harmful algal blooms. Progress in Oceanography 85, 5 (2010).

[Rose 15] C. Rose, A. Parker, B. Jefferson et E. Cartmell, The characterization of feces and urine: a review of the literature to inform advanced treatment technology. Critical reviews in environmental science and technology 45 , 1827 (2015).

[SalmonChile 18] SalmonChile, Production data (2018).

[Sernapesca 16a] Sernapesca, Doc 087486. 04 march 2016. Informe Tecnico Solicitud vertimiento al mar Salmonchile AG (2016).

[Sernapesca 16b] Sernapesca, IINFORME FISCALIZACIÓN DE LA RESOLUCIÓN D.G.T.M y M.M. ORD. Ną12.600/05/114/VRS, DE LA AUTORIDAD MARITIMA RELATIVA AL VERTIMIENTO DE DESECHOS DE SALMONES (2016).

[Sernapesca 16c] Sernapesca, Report from the Los Lagos Regional director of Sernapesca, to the comission of environment and natural resources from the House of representatives (2016).

[Sernapesca 17] Sernapesca, Public Report 2016 (2017).

[Sernapesca 18] Sernapesca, Environmental impact reports INFAs 2010-2018 (2018).

[SMA 16a] SMA, Res. ex. 1/D-063-2016. Formulación de cargos contra Australis Mar (2016).

[SMA 16b] SMA, Res. ex. 1/D-084-2016. Formulación de cargos contra Salmones Maullin (2016).

[Soto 04] D. Soto et F. Norambuena, Evaluation of salmon farming effects on marine systems in the inner seas of southern Chile: a large-scale mensurative experiment. Journal of Applied Ichthyology 20, 493 (2004).

[Strub 19] P. T. Strub, C. James, V. Montecino, J. A. Rutllant et J. L. Blanco, Ocean circulation along the southern Chile transition region (38ą-46ą S): Mean, seasonal and interannual variability, with a focus on 2014-2016. Progress in Oceanography (2019).

[Trainer 19] V. L. Trainer, S. K. Moore, G. Hallegraeff, R. M. Kudela, A. Clement, J. I. Mardones et W. P. Cochlan, Pelagic harmful algal blooms and climate change: Lessons from natureÕs experiments with extremes. Harmful Algae (2019).

[Varela 12] D. Varela, J. Paredes, C. Alves-de Souza, M. Seguel, A. Sfeir et M. Frangópulos, Intraregional variation among Alexandrium catenella (Dinophyceae) strains from southern Chile: Morphological, toxicological and genetic diversity. Harmful Algae 15, 8 (2012).

[Verdejo 18] J. Verdejo et S. Lorca, Marea roja: toxicidad en Aysén es siete veces superior al peak de 2009. La Tercera (2018). 